American University Washington College of Law

Digital Commons @ American University Washington College of

Law

Working Papers

Works

6-5-2009

\title{
Targeted Killing in U.S. Counterterrorism Strategy and Law
}

Kenneth Anderson

American University Washington College of Law, kanders@wcl.american.edu

Follow this and additional works at: https://digitalcommons.wcl.american.edu/fac_works_papers

Part of the Human Rights Law Commons, and the International Law Commons

\section{Recommended Citation}

Anderson, Kenneth, Targeted Killing in U.S. Counterterrorism Strategy and Law (May 11, 2009). Available at SSRN: http://ssrn.com/abstract=1415070.

This Article is brought to you for free and open access by the Works at Digital Commons @ American University Washington College of Law. It has been accepted for inclusion in Working Papers by an authorized administrator of Digital Commons @ American University Washington College of Law. For more information, please contact kclay@wcl.american.edu. 


\section{Targeted Killing in U.S. Counterterrorism Strategy and Law}

A Working Paper of the Series on Counterterrorism and American Statutory Law, a joint project of the Brookings Institution, the Georgetown University Law Center, and the Hoover Institution

\section{Kenneth Anderson*}

May 11, 2009

* Professor of Law, Washington College of Law, American University, and Research Fellow, The Hoover Institution, Stanford University and Member of its Task Force on National Security and the Law. Thanks to members of the Hoover Task Force who offered comments on an early presentation of this material; they are not responsible for any views expressed here. Thanks also to my research assistants at Washington College of Law, Can Celik, Neil Pandey-Jorrin, David Wiseman, and Scott Yoo. 


\section{Introduction}

It is a slight exaggeration to say that Barack Obama is the first president in American history to have run in part on a political platform of targeted killings - but not much of one. During the campaign, he openly sought to one-up the Republican nominee, Sen. John McCain, in his enthusiasm for the use of targeted strikes in Pakistan against al Qaeda figures. "You know," he said in his speech at the Democratic National Convention, "John McCain likes to say that he'll follow [Osama] Bin Laden to the Gates of Hell, but he won't even go to the cave where he lives." 1 That he would, as president, follow bin Laden to his cave, with or without the cooperation of the Pakistani government, he made perfectly clear. "If we have actionable intelligence about highvalue terrorist targets and President [Pervez] Musharraf won't act, we will," he said in another speech. ${ }^{2}$ Indeed, while he criticized President Bush for being too aggressive in many aspects of counterterrorism, with respect to targeted killings, his criticism was the polar opposite: "The Bush administration has not acted aggressively enough to go after al Qaeda's leadership," he said. "I would be clear that if Pakistan cannot or will not take out al Qaeda leadership when we have actionable intelligence about their whereabouts, we will act to protect the American people. There can be no safe haven for al Qaeda terrorists who killed thousands of Americans and threaten our homeland today."3

Obama did not take long, on assuming office, to begin keeping his promise. On January 23, 2009 a mere three days into his presidency, strikes by Predator drones in the tribal areas of Pakistan destroyed two compounds and killed numerous people, reportedly including a high-value target. ${ }^{4}$ Strikes continued, even expanded, over the successive months, and administration officials made clear that they had no plans to curtail themeven as they reined in coercive interrogations and announced the closure of Guantánamo Bay. ${ }^{5}$

Obama was right as a candidate and is correct as president to insist on the propriety of targeted killings - that is, the targeting of a specific individual to be killed, increasingly often by means of high technology, remote-controlled Predator drone aircraft wielding missiles from a stand-off position. The strategic logic that presses toward targeted standoff killing as a necessary, available and technologically advancing part of counterterrorism is overpowering. So too is the moral and humanitarian logic behind its use. Just as crucial programs of Predator-centered targeted killing are underway now in Afghanistan and, with increasing international controversy, Pakistan, over the long term these programs of stand-off targeted killing will be an essential element in United States counterterrorism into the future - and with targets having little or nothing to do with today's iteration of the war on terror. ${ }^{6}$ Future administrations, even if they naturally prefer to couch the matter in softer terms, will likely follow the same path. Even if the whole notion seems to some disturbingly close to arbitrary killing, not open combat, it is often the most expedient - and, despite civilian casualties that do occur, most discriminatingly humanitarian - manner to neutralize a terrorist without unduly jeopardizing either civilians or American forces. 
But there's a paradox in Obama's embrace of targeted killing: Even as the strategic and humanitarian logic for it increases in persuasiveness, the legal space for it and the legal rationales on which it has been traditionally justified are in danger of shrinking. They are at risk of shrinking in ways that might surprise members of Congress and the Obama Administration. And they are at risk of shrinking through seemingly innocuous, unrelated legal policy actions that the Obama Administration and Congress might be inclined to take in support of various political constituencies, usually related to broadly admirable goals of human rights and international law.

American domestic law - the law codifying the existence of the CIA and defining its functions - has long accepted implicitly at least some uses of force, including targeted killing, as self-defense toward ends of vital national security that do not necessarily fall within the strict terms of armed conflict in the sense meant by the Geneva Conventions and other international treaties on the conduct of armed conflict. Categories of the use of force short of armed conflict or war in a juridical sense- by intelligence services such as the CIA, for example - or by military agents in furtherance of national self defense and vital security interests, yet outside of the legal condition of armed conflict, date back in codified law to the founding of the CIA and, in state practice by the United States and other sovereigns, far further still. Yet as a matter of legal justification, successive administrations have already begun to cede this ground. Even the Bush Administration, with its unrivaled enthusiasm for executive power, always sought to cast its killing targets as the killing of combatants in what it legally characterized as armed conflicts, governed by the laws of war on the conduct of hostilities, known as "international humanitarian law" (IHL). This concession, however, if followed by the Obama Administration and beyond, will likely reduce the practical utility of a policy and security tool of both longstanding provenance and proven current value. It will likely reduce the flexibility of the United States to respond to emerging threats before they ripen into yet another war with non-state terrorists, and it will reduce the ability of the United Sates to address terrorist threats in the most discriminating fashion advancing technology permits.

At this moment in which many policymakers, members of Congress and serious observers see primarily a need to roll back policies and assertions of authority made by the Bush Administration, any call for the Obama Administration and Congress to insist upon powers of unilateral targeted killing and to claim a zone of authority outside of armed conflict governed by IHL that even the Bush Administration did not claim must seem at once atavistic, eccentric, myopic and perverse. Many will not much care that such legal authority already exists in international and U.S. domestic law. Yet the purpose of this chapter is to suggest that, on the contrary, the uses to which the Obama Administration seeks to put targeted killing are proper, but they will require that it carefully preserve and defend legal authorities it should not be taking for granted and that its predecessors, including the Bush Administration, have not adequately preserved for their present day uses.

People who threaten serious harm to the United States will not always be al Qaeda, after all. Nor will they forever be those persons who, in the words of the Authorization for the Use of Military Force (AUMF), "planned, authorized, committed or aided" the attacks of 
September 11. ${ }^{7}$ As I will explain, it would have been better had the Bush and Clinton Administrations, for their parts, formulated their legal justifications for the targeted uses of force around the legal powers traditionally asserted by the United States: the right of self-defense, including the right to use force even in circumstances not rising to the level of an "armed conflict" in order to have firmly fixed in place the clear legal ability of the United States to respond as it traditionally has. Although the United States still has a long way to go to dismember al Qaeda, its affiliates and subsidiaries, although Osama bin Laden and key al Qaeda terrorist leaders remain at large, and although the President of the United States still exercises sweeping powers both inherent and granted by Congress to use all national power against the perpetrators of September 11, time moves on. New threats will emerge, some of them from states and others from non-state actors, including terrorist organizations. Some of those new threats will be new forms of jihadist terrorism; others will champion new and different causes. Even now, Islamist terror appears to be fragmenting into loose networks of shared ideology and aspiration rather than tightly vertical organizations linked by command and control. ${ }^{8}$ It will take successive feats of intellectual jujitsu to cast all of the targets such developments will reasonably put in the cross hairs as, legally speaking, combatants.

Yet the problem is still deeper and more immediate than that, for the accepted space for targeted killings is eroding even within what a reasonable American might understand as the four corners of our conflict with al Qaeda. In many situations in which any American president, Obama certainly included, would want to use a targeted killing, it is unclear to some important actors - at the United Nations, among our allies, among international law scholars, and among NGO activists - as a matter of international law that a state of armed conflict actually exists or that a targeted killing can qualify as an act of self-defense. The legal situation, therefore, threatens to become one in which, on the one hand, targeted killing outside of a juridical armed conflict is legally impermissible and, on the other hand, as a practical matter, no targeted killing even within the context of a "war" with al Qaeda is legally permissible, either.

Congress's role in this area is admittedly a peculiar one. It is mostly-though not entirely_-politically defensive in nature. After all, the domestic legal authorities to conduct targeted killings and other "intelligence" uses of force have existed in statutory form at least since the legislation that established the Central Intelligence Agency in 1947 and in other forms long pre-dating that. ${ }^{9}$ The problem is that although domestic legal authority exists for the use of force against terrorists abroad, currents are stirring in international law and elsewhere that move to undermine that authority. Powerful trend and opinion-setting - so-called "soft law"-currents are developing in ways that, over time, promise to make the exercise of this activity ever more difficult and to create a presumption, difficult to overcome, that targeted killing is in fact both illegitimate and, indeed, per se illegal except in the narrowest of war-like conditions. The role of Congress is therefore to reassert, reaffirm, and reinvigorate the category as a matter of domestic law and policy, and as the considered, official view of the United States as a matter of international law. 


\section{The Strategic and Moral Logic of Targeted Killings}

American counterterrorism is a hybrid employing distinct palettes of legal tools. One is criminal law enforcement; another is armed conflict. ${ }^{10}$ Americans have been arguing about these two palettes - their relative uses, merits, and limitations - nonstop since September 11. Each occupies important ground in the legal and policy regulation of uses of force and violence in counterterrorism. As a matter of long-term counterterrorism strategy, each will continue to play an important role. Moreover, despite many nowfamiliar arguments, sometimes ferocious, over such issues as Guantánamo, habeas corpus, civilian versus military criminal trials, detention, rendition, and interrogation, each of these fields - law enforcement and armed conflict—-have well established legal and policy protocols.

Criminal law is not about killing people as such; it is, rather, about arresting, literally stopping their activities and punishing them for ones that violate the law. Resisting arrest can lead to deadly violence, but the paradigm of law enforcement is one that fundamentally takes place within an ordered domestic society in which the governmental use of deadly force is incidental to the attempt to arrest alleged criminals. That is, its virtue is that it takes place in a settled, ordered society with a legitimate government. That also represents its limitation in dealing with terrorists, who are at once enemies of that society and criminals in their methods and often shelter beyond the reach of its institutions. ${ }^{11}$

Armed conflict accepts a willingness to kill people in the pursuit of political ends, and those killings are not limited merely to killings incident to attempted arrest. Its virtue is that it is addressed to enemies who come from outside a settled society, but its limitation is that its uses of force are not underwritten with the legitimacy of a state in an ordered society. Policing and war-making are two radically different deployments of violence by the state, the former the exercise of a legitimate near-monopoly on violence and the latter the exercise of the level of violence dictated by military necessity so as to create a monopoly on violence. ${ }^{12}$ Yet core standards are reasonably clear for both criminal law and war law. To the extent that we debate these core standards, we normally do so on account of their uncertain application to an activity - terrorism by transnational non-state actors - that lies at the margins, rather than the core, of each.

Even pre-dating the September 11 era, ${ }^{13}$ however, counterterrorism as practice, law, and policy has also consisted of activities that do not fall neatly under either of these two existing legal regimes. ${ }^{14}$ Their broadest policy description is "intelligence," but that term encompasses an extraordinarily heterogeneous set of activities. These include classical intelligence gathering functions, such as surveillance-including telecommunications and Internet surveillance, human intelligence, satellite and observation intelligence, and analysis of material collected by whatever other means. They also include intelligence community, law enforcement, military, and diplomatic coordination and exchange of information with friends and allies abroad. They include - of ever-increasing importance - the interdiction of terrorist finances and the investigation, seizure, and freezing of economic assets essential to terrorist organizations. In this discussion, I 
loosely refer to all these activities as a "third" aspect of counterterrorism, a "third way of counterterrorism," or as "intelligence" activities in counterterrorism, despite their heterogeneity. ${ }^{15}$ And this third aspect of counterterrorism also includes the traditional intelligence function of the covert uses of force. ${ }^{16}$

Within the wide range of intelligence functions, one naturally stands out as especially controversial: the use of, or the threat to use, deadly force. For while intelligence activities raise many thorny issues of domestic and international law, particularly when conducted on foreign territory and in violation of local law and sovereignty, none is so difficult as those which involve killing people.

Call it a "war on terror," however, call it something else, it does not really matter. ${ }^{17} \mathrm{~A}$ full response to terrorism, to al Qaeda and beyond, requires actions across all three of these areas: criminal law, armed conflict, and "intelligence" functions, including covert deadly force and targeted killing. The Obama Administration and the administrations that follow it will rely increasingly on intelligence-based uses of force in counterterrorism undertaken outside the United States. However the activity is characterized as a legal matter or as a public relations label or policy euphemism, U.S. administrations will rely upon targeted killing as a means of dealing with suspected terrorists - with al Qaeda, its successors, imitators and emulators, and with those who come after it, whether they share similar or dissimilar ideological causes, and whether or not Congress has passed a successor to the Authorization for the Use of Military Force. ${ }^{18}$ The Predator and Hellfire missile were identified early on by candidate Obama as the weapons of the future, as the U.S. gradually seeks to ratchet down its full-on, overt wars. ${ }^{19}$ And the Obama Administration is not wrong to see the strategic advantages of the Predator, now and into the future.

This view is deeply embedded within the mainstream of President Obama's party. To cite only one example, note how unambiguously Democratic international relations and intelligence eminence grises Graham Allison and John Deutch endorsed the Predator policy with regards to Pakistan:

The counterterrorism strategy [of Predator strikes] in Pakistan that has emerged since last summer offers our best hope for regional stability and success in dealing a decisive blow against al Qaeda and what Vice President Joe Biden calls "incorrigible" Taliban adherents. But implementing these operations requires light U.S. footprints backed by drones and other technology that allows missile attacks on identified targets [emphasis added]. ${ }^{20}$

In response to the increasingly heard claim that the drone-and-missile targeted killing strategy backfires by inflaming Pakistani public opinion against the United States because of collateral civilian deaths - most recently, for example, from Australian counters=insurgency expert David Kilcullen, who urged Congress in testimony to "call off the drones" 21 -Allison and Deutch offer a remarkably realpolitik answer. If "many Pakistanis see covert actions carried out inside their country as America 'invading an ally," the problem is not the drone campaign, they write; it is, rather, merely that "the U.S. government no longer seems capable of conducting covert operations without having them reported in the press [emphasis added]."22 
There is a fundamental strategic and moral rationale lying behind both the policy trend toward targeted killing and toward the use of robotic and stand-off platforms such as the Predator drone as the preferred means of effectuating it. The United States has found the limits of how extensively it can wage full-scale wars with its military; even if it wanted to take on more wars, it has logistical and political limits. In addition, the United States has discovered that full-on war is useful principally against regimes. Full-scale, large-scale warfare of the kind waged in Afghanistan and Iraq is useful primarily for bringing down a government that, for example, might harbor or support terrorists, or which might be believed to be willing to supply terrorists with materials for weapons of mass destruction. While this tool has a crucial strategic place in national counterterrorism policy, by its nature, its role is about states and state-like groups. Large-scale military operations are less useful directly against transnational terrorists, who are few in number, dispersed across populations and often borders, disinclined to fight direct battles, and more efficiently targeted through narrower means. The fundamental role of overt warfare in counterterrorism is to eliminate the regimes that provide safe haven to terrorist groups; terrorist groups themselves can be strategically understood as an extreme version of a guerrilla organization engaged in a strategy of logistical raiding - in which civilian morale and the resulting manipulation of political will is the logistical target. ${ }^{23}$ Logistical raiders typically need a safe base to which to retreat, and full-scale war is most useful in eliminating such safe bases and convincing other regimes not to provide them. ${ }^{24}$ But it is not usually an efficient way of going directly after the transnational terrorist groups themselves. $^{25}$

Law enforcement utilized outside the United States, on the other hand, has also discovered its outer limits. Many debates are still to be had over the rights of alleged terrorists once in U.S. custody. But whatever they are, few would argue that going out to "arrest" terrorists in, for example, Pakistan's tribal zones is a winning policy or a serious option. The same is true in Somalia and other places, and it will be true in other places in the world in the future.

Moreover, the political costs for any U.S. administration in taking and holding detainees are now enormous. ${ }^{26}$ Once you hold them, over time, they will likely be accorded quasiConstitutional protections by the courts in some matters, and they will receive at least some version of habeas corpus. Politically, the most powerful institutional incentive today is to kill rather than capture them. The intelligence losses of killing people, rather than capturing and interrogating them, are great. ${ }^{27}$ But since the U.S. political and legal situation has made aggressive interrogation a questionable activity anyway, there is less reason to seek to capture rather than kill. And if one intends to kill, the incentive is to do so from a standoff position, because it removes potentially messy questions of surrender.

All of this speaks to the advantages to the U.S. government of targeted killing of terrorists or persons seriously believed to be terrorists; it also speaks to the advantages to the government of using stand-off robotics technology to perform these attacks. But the humanitarian advantages of targeted killing are enormously important as well and ought to be on the table. This is particularly so given that targeted killing has come in for a 
barrage of criticism, legal and ethical, much of which seems perversely motivated by the fact that it can be more discriminate than full-scale military assault. ${ }^{28}$ The fear seems to be that targeted killing using Predators and other robotics systems "lower[s] the threshold for violence." ${ }^{29}$ It makes violence too easy to undertake. ${ }^{30}$

The same criticism is offered of evolving robotic technology that increasingly allows targeted uses of force without having to risk one's own personnel. Not using one's own personnel allows a party to attack without the fear of counterassault that might increase the need to use greater amounts of force and cause greater collateral damage - but it also, so it is sometimes argued, thereby reduces the inhibitions on the decision to use force. ${ }^{31}$ Military technology theorist P.W. Singer, for example, says of robotic unmanned weapons systems: "When faced with a dispute or crisis, policymakers have typically regarded the use of force as the 'option of last resort.' Unmanned systems might now help that option move up the list, with each upward step making war more likely." 32

Whatever the critics say, however, is unlikely to sway U.S. strategic policy under the Obama Administration or anyone else subsequently. ${ }^{33}$ The humanitarian benefits of precision targeting are far more obvious than the more remote and abstract suppositions of their humanitarian costs. Their direct policy consequence is to introduce greater discrimination in targeting than full-scale military assault and large-scale war permit. Advancing technology allows for more discrete surveillance and, therefore, more precise targeting that is better able to minimize collateral civilian damage. This is a good thing for those who do not want to kill innocent civilians. Indeed, humanitarians long called upon advanced militaries to shift from designing more destructive weapons systems to designing more discriminating ones; weapons designers have been seeking to comply over decades, and there is something perverse about now criticizing their evolving efforts as making war so much less destructive and so discriminating as to be too easy to undertake.

The result is a strategic and moral incentive for targeted killing and for increasing the quality of technology to make targeted killings both more precision-targeted and more standoff. Precision targeting and standoff delivery are each independently desirable and, in combination, considerably increase this incentive.

None of this alters the equally impeccable strategic logic underlying the use of law enforcement mechanisms in some circumstances. Nor does it alter the logic behind other forms of intelligence activities, such as surveillance or financial interdiction, or even the use of open, full-on war. ${ }^{34}$ We can by no means rule out the toppling of a regime in pursuit of counterterrorism during the next ten or twelve years. But these are not disjunctive policies. Targeted killing is likely to increase as a policy preference as fullscale wars decrease in number and intensity and become less desirable as a means of effectuating counterterrorist objectives. Bush's Iraq adventure has surely reduced the American appetite for invading the tribal regions of Pakistan, for example, and something has to fill the gap. That need is partly what has augmented the Predator's appeal, especially to the Obama Administration. No doubt there will be political pushbackclaims that the effect of the Predator campaigns in Pakistan are backfiring by mobilizing 
Pakistani anger at civilian casualties, for example. But given the political unreliability and military ineffectiveness of the Pakistani army and its preference for artillery barrages over focused counterinsurgency, these arguments are not likely to persuade.

The United States has long accepted a legal, political, and policy space for the use of force that does not take place in the course of judicially supervised law enforcement operations but also takes place outside of the context of large-scale, open armed conflict meeting the treaty definitions, or rising to a sufficient level of violence, so as to be governed by IHL. This was a space of activity accepted and considered vital to selfdefense and national security throughout the long decades of the Cold War. Only in certain narrow times and places, after all, was the conflict with the Soviet Union and its allies a "hot" war, characterized by open and large-scale armed conflict, the sort of clashing of armies formally governed by IHL. ${ }^{35}$ Political violence during the Cold War was often covert, often denied, but it was authorized and endorsed by American domestic law, dating back at least to the statutes founding the CIA in 1947. That was so even though the activity in question frequently violated the law and sovereignty of states in which it took place and unsurprisingly was sometimes, too, a source of grave diplomatic and other friction. Following the revelation of abuses by the CIA in the 1970s, U.S. domestic law was tightened, "assassination" prohibited by President Ford's 1976 Executive Order, and Congressional oversight mechanisms strengthened. But, as discussed below, far from eliminating this category of violence by limiting such uses of force solely to "armed conflict" in the meaning governed by IHL, U.S. domestic law quietly and intentionally preserved the category while strengthening the oversight.

This category of force is now an obvious means by which to confront non-state transnational terrorists outside the territorial United States. The United States is no longer in the Cold War. But the legal and political regimes that it (and other states, both friend and foe) elaborated through state practice, allowing uses of covert and discrete force as a matter of self-defense, are, if anything, more relevant in confronting transnational terrorism today. Yet as matters now stand, great pressures will come to bear against the very existence of this legal and political category-great precisely because they are idealistic and morally well-intended. Should these pressures prevail, they will bind the hands of the President and Congress so as to prevent them from taking what is paradoxically the most discrete and most precisely-targeted lethal measures available against terrorists. The result would be to throw the United States into the much more difficult policy dilemma of using larger-scale military activity against terrorists or taking no very meaningful action at all. ${ }^{36}$

\section{Targeted Killing and Armed Conflict}

Targeted killing is not a generally defined legal term in domestic or international law. ${ }^{37}$ For our purposes, I take it here to mean the intentional, direct targeting of a person with lethal force intended to cause his death. It is not an unintended collateral killing. Targeted killings can sometimes occur in law enforcement, for example the killing of a hostagetaker in order to save the victim or, for that matter, capital punishment. Likewise, they 
frequently and without particular controversy take place as part of overt, open armed conflict - circumstances in which IHL is unquestionably the paradigm of law-in-force. While there are some important questions about the application of the rules of targeted killings in situations of unquestioned, open, large-scale armed conflict, the pattern of rules under IHL is relatively clear. ${ }^{38}$

The trouble for the United States arises because, as the war on terror migrates away from the most overt of armed conflict situations, the question of whether a given targeted killing takes place in a legally cognizable armed conflict becomes open to debate. This might seem surprising, given the importance of targeted killing as part of armed conflict in U.S. military doctrine and its importance in both the Afghanistan and Iraq wars, as well as the extension of the Afghanistan operation into Pakistan. Predator strikes have been important in all of those operations, and anyway they are not the only kinds of "covert," unacknowledged operations involving both military and CIA personnel taking place in Pakistan and elsewhere. ${ }^{39}$ But at least if armed conflict means as a matter of law anything more than the mere fact that a party has undertaken to use lethal force, it is not always clear that these killings are actually targeted killings within, rather than outside of, armed conflict.

This anomaly reflects different legal meanings and standards, pursuant to different legal instruments and regimes, for the term "armed conflict." The problem is not merely that terms have one meaning in the ordinary parlance and another in legally precise contexts. One scholar points out that the recent massive, three volume, four thousand-plus page International Committee of the Red Cross study on the customary law of international humanitarian law "included nothing on the definition of the term, because it remains much disputed...[and] terminological disputes are rife; several commentators express doubt, for instance, that attacks even by well organized terrorist groups like al Qaeda can constitute 'armed attacks' within the meaning" of the UN Charter and, by implication, the international law of self-defense. ${ }^{40}$

International lawyers argue over the meaning of "armed conflict," starting with the most basic question: Is it a term referring specially to the law of "resort to force," or to the conduct of warfare, IHL, or both? Eminent legal scholar and former West Point law professor Gary Solis states flatly, for example, that for a targeted killing to be lawful, "an international or noninternational conflict must be in progress. Without an ongoing armed conflict the targeted killing of a civilian, terrorist or not, would be assassination - a homicide and a domestic crime." ${ }^{, 41}$ But that only raises the question of what constitutes an "armed conflict" in the first place.

Does the prohibition to which Solis alludes refer to armed conflict in the sense of a resort to force in self-defense? Or instead to armed conflict within the meaning of IHL, governing not the decision to resort to force, but how the use of force is conducted in hostilities? If the former, then the long-existing structure of civilian CIA authority to act in accordance with domestic law makes sense. If the latter (or both), then the lawful function of the CIA to use force becomes unclear at best, because it is a civilian agency 
with authority to act, as discussed below, outside of contexts involving IHL armed conflict.

The stakes on this question are high, because the international legal standards that must be satisfied are radically, conceptually different. They answer sharply different questions. International law governing the resort to force is fundamentally about separating legitimate self-defense from illegitimate aggression. IHL, by contrast, does not address the legitimacy of the resort to force, but instead addresses the conduct of any party in an armed conflict. It is concerned, at bottom, with the conduct of the parties in hostilities, with separating combatants from noncombatants. It does not apply to every resort to force - only those that meet particular treaty requirements or rise to a certain level of violence constituting IHL "armed conflict." Yet if it's really simple murder legally, as Solis suggests, to engage in a targeted killing outside of such armed conflict — even if in lawful self-defense - then the United States has a big problem.

In the common, lay understanding of the term "armed conflict," at least, it is obvious that the United States is engaged in one in Pakistan; its aircraft and missiles are engaged against targets there, and it sends in special forces and other personnel to engage in fighting as well. Again, in the common understanding of the term, it was only a little less obvious that a Predator strike against an al Qaeda figure fleeing in a vehicle across the desert in Yemen was part of America's "armed conflict," its war, against al Qaeda. For that matter, in that same common understanding - if not, perhaps surprisingly, in the views of all legal commentators-September 11 itself constituted an armed attack, an undertaking in an armed conflict initiated by al Qaeda. Even if al Qaeda is a non-state actor using criminal ends, September 11 was an act at once part of an armed conflict and also a crime.

But as a question of IHL, whether something is an "armed conflict" to which the rules of warfare apply is not settled simply by saying that a party - the United States - has undertaken a targeted killing and therefore is engaged in armed conflict governed by IHL. The U.S. government, after all, might simply have engaged in murder. The same is true for an al Qaeda attack. The fact that both al Qaeda, a non-state actor, and the United States regard themselves as in a state of war with one another is peculiarly immaterial as well to the question of whether IHL applies. Rather, the question of whether a "resort to force" in any particular circumstance triggers the application of IHL depends upon a specific set of triggers contained in applicable IHL treaties, starting with the Geneva Conventions and the Hague Regulations. These triggers depend first on the applicable language of the relevant IHL treaty defining its application and, next, on whether the fighting has reached some factually determined threshold level between the parties. ${ }^{42}$ Very roughly, this requires either hostilities between two states or else, in the case of non-state actors - such as in a civil war-fighting that is on-going, persistent, widespread, and organized. A resort to force might well raise an international law question of whether it constitutes, on the one hand, an act of aggression or, on the other, a lawful resort to self-defense. But that is a separate question from whether the particular resort to force also invokes IHL as the law governing the conduct of that resort to force. Running these two questions together leads to serious problems. The most serious is that what the 
United States regards as lawful armed conflict might well be regarded by much of the rest of the world as something close to simple murder.

The overall point for present purposes is that targeted killing against a non-state actor by either the armed forces of a state or its civilian agents (such as the CIA) does not automatically, by reason of the use of force alone, trigger the application of IHL. Nor does the fact that since the African embassy bombings in the 1990s, the United States has seen itself as in a state of armed conflict with al Qaeda and additionally, under the AUMF and domestic court rulings, in an armed conflict with those responsible for the September 11 attacks.

At the moment, few in the United States seem much to care about this problem. After all, the struggle with al Qaeda seems intuitively covered as an armed conflict under IHL, so the distinction I'm making here and the concern I'm raising about the resulting legal jeopardy for those engaged in carrying out or authorizing targeted killings must be a kind of paper tiger, a remote law school hypothetical with no bearing on actual policy. But for an administration committed to this strategic instrument to view the problem thus would be a significant mistake. As the war extends into Pakistan, extends to targets beyond al Qaeda "combatants" (whatever precisely that means), and into places such as Yemen or Somalia, then these questions of whether targeted killings outside of legally cognizable armed conflict can be legal reemerge, and in sometimes surprising ways. And they emerge even more acutely if - when - at some point in the future, threats to the United States do not come from al Qaeda at all but from some other group against whom Congress has not passed an authorization for force buttressed by resolutions of the Security Council. ${ }^{43}$

\section{The Stakes over Targeted Killing}

Even accepting that there are two quite different meanings of "armed conflict," is there anything actually at stake here? I have suggested rather ominously that if the United States does not move to protect and assert its long-held legal positions relative to targeting killing, it stands to lose them. But is there any good reason to think this is true? After all, the Obama Administration does not appear to see a problem with its legal rationales. Neither did the Bush or Clinton Administrations before it. The war on terror, they have all contended, is armed conflict on some theory or other.

But there are two problems here. The first is the long-term issue to which I earlier alluded: Whether, in some future conflict unrelated to al Qaeda, situations might arise that do not meet all definitions of armed conflict. The second is a more immediate problem: A close look at the way international law is formulated and interpreted and the manner in which it is developing suggests that even the Obama Administration's current targeted killing policies are likely to come under much greater pressure than recent administrations have understood. 
Let's start with what is now the standard view among the leading academic experts on the subject of targeted killing. The scholarly community, as Mark Osiel accurately says, "is almost entirely hostile to the practice, sanctioning it only under the most restrictive conditions, of a sort that can virtually never be satisfied in practice." 44 Nils Melzer's formidable treatise, Targeted Killing in International Law, ${ }^{45}$ for example, starts from the premise that the only two possible paradigms for addressing even the concept of targeted killing are judicially-monitored law enforcement and armed conflict under IHL. "[O]utside the conduct of hostilities," he writes, "the extra-custodial killing of an individual cannot be the actual purpose, but must remain the undesired and inevitable consequence, of an operation absolutely necessary to achieve a different, legitimate aim." 46

By "hostilities" here, Melzer does not mean armed conflict in some colloquial sense-nor in the sense of military action in a country's self-defense. He means in the technical sense of IHL. That this is the leading treatise's premise, rather than its conclusion, gives some sense of how far American domestic political views in the centrist political spectrum are from the views of the "international law community," of which Melzer's views are representative. This view alone, if adopted by the International Criminal Court or a European magistrate with broad jurisdiction in human rights matters, could make murderers and war criminals out of President Obama and any of the people working for him on targeted killings. Far-fetched? A forthcoming Naval War College "Bluebook" article remarks in passing that cross-border operations in Pakistan might potentially expose "U.S. military personnel to international criminal liability." 47

But the argument goes further and deeper. Indeed, the most insistently offered objections are not simply definitional arguments about the words "armed conflict." They also involve human rights law and arise from the human rights claims of the individuals targeted, generally under the International Covenant on Civil and Political Rights (ICCPR). ${ }^{48}$

The ICCPR is a core United Nations treaty in the protection of human rights, rooted in the same process that led to the Universal Declaration of Human Rights. ${ }^{49}$ It is a broad statement of civil and political rights in international law, and establishes a long series of important guarantees related to physical and personal integrity_-including guarantees against arbitrary killing and extra-judicial execution. ${ }^{50}$ The ICCPR is the fundamentalalthough not the only-international human rights treaty that poses a challenge to the practice of targeted killing, by finding it to be extrajudicial execution or something similar. It has as of this writing at least 164 ratifications.

The United States ratified the ICCPR in 1992 but, like many countries, entered a number of treaty reservations, understandings, and declarations that limit the application of its terms in American conduct and law. ${ }^{51}$ The United States has taken much criticism for these steps, as well as for the fact that the Senate ratified the treaty with the express understanding that it created no private rights of action to enforce its terms judicially. ${ }^{52}$ Most important for purposes of targeted killing, the United States has never accepted that the ICCPR applies extraterritorially — that is, that it regulates U.S. actions beyond its 
borders. ${ }^{53}$ And it has always flatly rejected the application of the ICCPR in the setting of armed conflict. Legal protection for the U.S. ability to use Predators depends in no small part on preserving the American insistence, first, that the ICCPR does not apply extraterritorially and, second, that it does not apply in IHL armed conflicts, in which IHL substitutes as the legal regime in force, superseding ordinary human rights law.

The difficulties for American counterterrorism were the ICCPR conceded to apply extraterritorially would be compounded immeasurably by the growing belief that human rights law, and the ICCPR particularly, continue to apply in some fashion even during hostilities. As with the definition of armed conflict, here too the American position is an increasingly alienated one. The Organization of American States Inter-American Commission on Human Rights, for example, advanced the contrary position in recent years in a report on U.S. counterterrorism. ${ }^{54}$ Whether the United States will continue to hold the line-and whether policymakers understand the stakes in holding the line with respect to the Predator campaign in Pakistan and any other recourse to targeted killing in the future-is far from clear. It is also unclear what the meaning of these human rights standards is supposed to be in armed conflict. But from the standpoint of NGO advocates, that lack of clarity is itself a virtue, allowing a game of post hoc bait-and-switch for the legal rules on nearly any topic in armed conflict and a way to always reach a result one likes.

Congress and the Obama Administration will come under considerable pressure to cede this ground, because from the standpoint of advocates, access to the ICCPR, whether extraterritorially or within the United States, particularly in judicial proceedings, offers the much-sought human rights advocate's dream of an end-run around inconvenient (if democratically-enacted) U.S. domestic law. These advocates, it bears emphasis, are not marginal people. For example, Harold Koh, slated to become State Department legal advisor, signed a letter in 2008 stating that the ICCPR applies to armed conflict and implying that it must apply extraterritorially as well. ${ }^{55}$ And in his confirmation proceedings following his nomination to the State Department, he conspicuously did not retract this view of extraterritorial application - stating merely that he looked forward to reviewing the American position in the interagency process. ${ }^{56}$

Response to American practice on the part of human rights groups and international organizations has largely tracked the scholarly theoretical consensus. In response to the killing of Haitham al-Yemeni with a CIA Predator strike in Pakistan in 2005, Amnesty International said that, assuming the facts as it described them, the "USA has carried out an extrajudicial execution, in violation of international law." Amnesty believes that the governments of the "USA and Pakistan should have cooperated to arrest Haitham alYemeni rather than kill him." The fundamental reason it gave was that whether or not this was part of an armed conflict, international human rights law continued to apply to this situation. ${ }^{57}$ Amnesty takes the position, in other words, that human rights law-including broad rights against arbitrary killing and guaranteeing due process - should have applied in this instance irrespective of whether it was an armed conflict or not. It is hard to see the circumstances in which a targeted killing could be permissible under such a standard, which is precisely Amnesty's point. 
Similarly, very few people in the United States, regardless of political persuasion, would regard the Predator strike in Yemen on November 3, 2002-which killed six people, including a senior member of al Qaeda, Qaed Salim Sinan al-Harethi, in a vehicle on the open road - as anything other than a good thing, regardless of how one characterizes it legally. Yet the U.N. Special Rapporteur on extrajudicial, summary or arbitrary executions described it as a "clear case of extrajudicial killing." 58 The legal analysis followed that held by Amnesty International and many others - to wit, that it does not matter whether the targeted killing takes place in armed conflict or not, nor how the United States justifies it legally, because international human rights law continues to apply no matter what and to require that the governments involved seek to arrest, rather than to kill.

A subsequent U.N. special rapporteur on extrajudicial, summary or arbitrary executions summarized his office's view in 2004: "Empowering Governments to identify and kill 'known terrorists' places no verifiable obligation upon them to demonstrate in any way that those against whom lethal force is used are indeed terrorists, or to demonstrate that every other alternative had been exhausted." ${ }^{, 59}$ Once again, it is hard to see how targeted killing as a policy could survive in any form with such a legal characterization.

Various European allies have been extremely hostile toward the practice. Swedish Foreign Minister Anna Lindh was among the most outspoken critics of the U.S. targeting of al-Harethi in November 2002. She described the operation as "a summary execution that violated human rights...Even terrorists must be treated according to international law. Otherwise any country can start executing those whom they consider terrorists." $" 60$ The criticism is even stronger when the actor is Israel-which undertakes targeted killing in keeping with the peculiarly long-term, "mixed" war-security and intelligence-law enforcement nature of its struggle - and, incidentally, with far more procedural protections than the United States uses, including judicial review. Then the gloves come off completely in expressions of international hostility to the practice. ${ }^{61}$

To be clear, under the standards these groups are articulating, these practices are regarded as crimes by a sizable and influential part of the international community. This is so whether or not these acts are currently reachable by any particular tribunal. As the coercive interrogation debate shows, with Spain and other countries considering prosecutions in their own courts, the trend is toward an expansion of jurisdiction of such tribunals. And America's claim that these are killings of combatants in an armed conflict governed by either self-defense or IHL does not cut much ice against the views of those who either reject the armed conflict claim outright or else claim that even in armed conflict, human rights standards will apply.

American officials seem to believe that by appealing to the detailed and specific requirements of IHL on the formal and technical definition of combatancy as an apparent condition of finding a lawful target, they have done an especially good and rigorous parsing of the legal requirements. As far as the international law community is concerned, however, the combatancy standard is not some especially rigorous approach 
that shows how concerned a party is for international law. To the contrary, it is by definition a relaxation of the ordinary standard of international human rights law, including prohibitions on murder and extrajudicial killing - and it can only be justified by the existence of an armed conflict that meets the definitions of IHL treaties.

At times it appears that the United States government has little idea how much its concession of formal requirements of combatancy concedes. Yet when the United States argues that it's okay to target someone because he is a combatant, it effectively concedes that the conflict must meet the definition of an IHL conflict for such an attack to be legitimate. By contrast, what the United States needs, and its historic position has asserted, is a claim that self-defense has an existence as a doctrine apart from IHL armed conflict that can justify the use of force against an individual. The United States has long assumed, then-Legal Adviser to the State Department Abraham Sofaer stated in 1989, that the "inherent right of self defense potentially applies against any illegal use of force, and that it extends to any group or State that can properly be regarded as responsible for such activities." 62

To put the matter simply, the international law community does not accept targeted killings even against al Qaeda, even in a struggle directly devolving from September 11, even when that struggle is backed by U.N. Security Council resolutions authorizing force, even in the presence of a near-declaration of war by Congress in the form of the AUMF, and even given the widespread agreement that the U.S. was both within its inherent rights and authorized to undertake military action against the perpetrators of the attacks. If targeted killing in which the international community agreed so completely to a military response against terrorism constitutes extrajudicial execution, how would it be seen in situations down the road, after and beyond al Qaeda, and without the obvious condition of an IHL armed conflict and all these legitimating authorities?

In the view of much of the international law community, a targeted killing can only be something other than an extrajudicial execution - that is, a murder-if

- It takes place in an armed conflict;

- The armed conflict is an act of self-defense within the meaning of the UN Charter, and

- It is also an armed conflict within the meaning of IHL; and finally,

- Even if it is an armed conflict under IHL, the circumstances must not permit application of international human rights law, which would require an attempt to arrest rather than targeting to kill.

As a practical matter, these conditions would forbid all real-world targeted killings.

As we now turn to see, the United States has never accepted these criteria. The result is that a strategic centerpiece of U.S. counterterrorism policy rests upon legal grounds regarded as deeply illegal-extrajudicial killing is one of the most serious violations of international human rights, after all, as well it should be-by large and influential parts of the international community. The change of administration from Bush to Obama gives some protection to the policy, but not likely for all of the Obama term and still less likely beyond it. We turn now from how the international law community sees targeted killing to U.S. views of the subject under both international and domestic law. 


\section{The American View of Targeted Killings}

How does the United States legally justify its targeted killing practices today? This is not an easy question to answer definitively, because much of the legal analysis and background is not public. Even where one gets hints, through Justice Department opinions made public, for example, one does not know if the entire record is on the table, and what facts, still under wraps, lawyers might have relied upon in their legal analyses. Drawing on publicly available information and some informal, anecdotal discussions with former government officials, however, we might hazard some assumptions about current legal policy.

Beginning apparently with the Clinton Administration, when the intelligence community first became aware of the threat from al Qaeda, the United States has seemed to justify at least some of its targeted killings by treating them as armed conflict by dint of their being acts of self-defense but then additionally asserting that the person in question is a lawful target under IHL. The legal rationale appears to conflate the questions of resort to force and armed conflict under IHL. The determination thus appears to become whether the target qualifies as a "combatant" who may be targeted under IHL. The fundamental difficulty with this approach is that it conflates the general customary obligations of necessity and proportionality under the international law of self-defense with the treatyspecific definition of a combatant under IHL. As I have explained, these obligations share certain roots but are not the same.

For example, the 9/11 Commission reported that the Clinton Administration justified legally an (ultimately abortive) operation to kill bin Laden in Afghanistan in 2000 on grounds that "under the law of armed conflict, killing a person who posed an imminent threat to the United States would be an act of self-defense, not an assassination.",63 During this period of time, of course, the United States was clearly not in a state of armed conflict in Afghanistan, and the incident predated the AUMF as well. While the rationale here invokes self-defense, it then turns to invoke the "law of armed conflict" without, however, specifying whether it is the law of resort to force or the IHL law of conduct of hostilities. Indeed, it is not clear whether the rationale treats a person who poses an "imminent threat" as a combatant who may be targeted per se-IHL would on its own terms impose a more exacting analysis of combatancy and "direct participation in hostilities" - but certainly the framework runs the risk of rationale by circular fiat: if we regard the person as an imminent threat, the person becomes by that fact alone a combatant.

Discussions with former officials suggest that successive administrations have not considered this to be a problem. "Why not?" they ask. The method of legal rationale appears to have been, from the 1990s until today: "We know we have been in a state of armed conflict with al Qaeda, whether under self-defense or IHL, so it does not really matter which one. Developments since September 11 have confirmed all this through the AUMF and Security Council resolutions and much else besides. So the question is really 
moot whether it is the law of resort to force and self-defense, or instead IHL and standards of combatancy. We have an armed conflict, so why worry about the question of whether it is based on one body of law or another?"

The real issue - one emphasized in these informal conversations - seems to be that without a basis for targeting directed against a "combatant," the targeted killing would become an "assassination." As discussed below, assassinations are specifically prohibited by U.S. domestic regulations, and they are legally separate from the international law questions of extrajudicial execution. If this is the proper way of interpreting assassination under American domestic law, then the effect is to force the U.S. into a legal analysis based around combatancy.

This framework for legally analyzing targeted killing decisions has the virtue of taking advantage of the fact of broad - although far from universal - agreement that America is at war with al Qaeda in some sense. Although discomfort with this paradigm might ripen eventually to the point of making individuals potentially liable for authorizing extrajudicial executions under the guise of the laws of armed conflict, we have not yet reached that point. So the path of least resistance over the past fifteen years works for now to some degree. But it will not work either if the international law community's view of the subject gains further traction, particularly in the context of states or tribunals that claim universal jurisdiction over human rights violations, or if the United States feels compelled to take on targets with whom it is not as clearly at war as it is with al Qaeda.

\section{Targeted Killing as Self-Defense?}

As I have already let on, the proper international legal rationale for targeted killing is self-defense, not that the target is a combatant under IHL. Unfortunately, self-defense is one of the most contested issues in all of public international law. The U.N. Charter says, at Article 2(4), that all member-states shall "refrain in their international relations from the threat or use of force against the territorial integrity or political independence of any state." It also goes on to say, at Article 51, that nothing in the present Charter shall "impair the inherent right of individual... self-defence if an armed attack occurs against a Member of the United Nations." As readers are likely well aware, the potential conflicts between these two articles (as well as the potential conflicts and interpretive issues, especially with respect to the meaning of "armed attack" and the "inherent" right of selfdefense under customary law, long predate the Charter) fill whole libraries of commentary. In this discussion, I confine myself strictly to the question of how a targeted killing might be viewed with respect to self-defense. ${ }^{64}$ Even so, the question remains alarmingly broad, on account of the fact that targeted killing is an activity on the cusp of perhaps the most difficult practical issue of self-defense: preemption and prevention and anticipatory self-defense. ${ }^{65}$

There are many views on this question and nearly endless controversies. But in the longstanding U.S. view, self-defense encompasses at least three categories:

- Self-defense against an actual use of force or hostile act; 
- "Preemptive self defense against an imminent use of force;" and

- "Self defense against a continuing threat."

These categories of U.S. interpretation are not new. ${ }^{66}$ Senior Department of Defense law of war lawyer Hays Parks noted them, for example, in a memorandum on assassinations back in 1989, long before the emergence of al Qaeda or the circumstances of September 11. ${ }^{67}$ Broadly speaking, the United States grounds its customary law views concerning anticipatory self-defense on the so-called Caroline Doctrine, which permits such actions but also limits them to circumstances in which the "necessity of self-defense is instant, overwhelming, leaving no choice of means, and no moment for deliberation." ${ }^{68}$ Despite the apparent restrictiveness of the Caroline language, and despite the fact that many international law commentators regard it has having been superseded or at least severely curtailed by the U.N. Charter, it has served as a source of evolving state practice for the United States view since before the Civil War down to the present day, and has been seen as a source of legal justification for preemptive and preventative self-defense. One corollary of the long-standing American interpretation (but widely reflected in the views and state practice of other states since 1945) of self-defense is that, notwithstanding the apparent literal language of Article 51, no "armed attack" need have occurred "before a state may use force to counter a threat." ${ }^{69}$

Moreover, as Parks also noted, the United States has always interpreted international law (including the Caroline Doctrine) so as to allow it to respond to the emergence of new kinds of threats. ${ }^{70}$ These interpretations include the self-defense right to respond to nonstate actors, such as al Qaeda (indeed, the Caroline Doctrine originally concerned a nonstate actor at the U.S.-Canadian border in 1837). And the United States also appears to have accepted some evolving version of what has sometimes been called the "accumulation of events" or "active defense" view of anticipatory self-defense-a variation of the category of "self-defense against a continuing threat." As one scholar describes this "active defense" view:

A state may use past practices of terrorist groups and past instances of aggression as evidence of a recurring threat. In light of this threat, a state may invoke [the right of self defense]... if there is sufficient reason to believe that a pattern of aggression exists. What may appear to be retaliation is quite often an "active defense" in which a state uses past terrorist acts to justify launching preemptive strikes. Advocates of this theory believe that it offers a much more practical response to a terrorist threat; in effect, a state will no longer need to wait until it is attacked before it may use force. ${ }^{71}$

This theory unsurprisingly suffered something in prestige when Saddam Hussein's Iraq turned out not to have weapons of mass destruction. Nonetheless, it remains the legal view of the United States, particularly with regard to terrorist non-state-actors. It almost unquestionably remains the view of the Obama Administration, which has been notably slow formally to relinquish legal powers of counterterrorism exercised under the Bush Administration. The legal policy of the United States has remained remarkably stable on this topic; as Hays Parks stated in 1989, the right of self-defense would support direct attack — and we can add, targeted killing — on terrorist leaders when "their actions pose a continuing threat to U.S. citizens or the national security of the United States." ${ }^{, 72}$ That is not narrow language, and it was not devised after September 11 or by the Bush 
Administration, but was an accurate statement of American policy in the 1980s. Through the Clinton Administration, the Bush Administration, and down into the Obama Administration today, some version of self-defense has remained the true, if sometimes obfuscated, underlying legal rationale for targeted killings.

What does this mean for targeted killing under international law, under long-standing U.S. views? Three things primarily: First, the United States accepts as a matter of international law that a targeted killing requires justification in some fashion as selfdefense in order to be a legal resort to force. Second, however, the American view of international law governing self-defense is pragmatic, flexible, and changes over time to meet new circumstances. Third and crucially from the standpoint of protecting the American legal position, the question of whether something plausibly constitutes selfdefense is debated by many different "communities of interpretation" of international law, including states, congeries of states, academics and non-governmental organizations, the Security Council, the General Assembly, and the International Court of Justice. That said, the United States is entitled to assert its own interpretation of international law should it choose to make the effort to do so-and provided it is willing to bear possible substantial international diplomatic costs. That requires, however, being willing to assert it and reassert it over time, to announce a view and to act upon that view.

The trouble, once again, is that much of the world sees the American right of self-defense far more narrowly. Important actors in the community of international law do not even accept that the situations in which the United States has undertaken targeted killing in, for example, Pakistan constitute legitimate self-defense under the U.N. Charter. For example, the eminent international law scholar Sean D. Murphy has a forthcoming article in the influential U.S. Naval War College's International Law Studies journal expressing grave and careful concern that, in the absence of meaningful consent by the government of Pakistan, a broad "right of self-defense against al Qaeda targets in Pakistan based on the attacks of 9/11, however, is...problematic, since the requirements of necessity and proportionality likely preclude unilateral uses of force against a third State that was not implicated in those attacks."73

The gap between U.S. needs and consequent views of self-defense and the views of the international law community is probably unbridgeable. But this is not a case of the United States versus the rest of the world. There are, rather, a sizable number of states that have to worry about the possibility of enemies using havens in third countries, shielded by claims of that third country's sovereignty. It is a delicate dance in international law; no one wants to say too much one way or the other, and when actual instances of state practice occur, very often the reaction is a discreet silence. Thus, leaving aside the United States or Israel, Murphy notes that Turkey has undertaken "various cross-border operations against the Kurdish separatist guerrilla organization... without being condemned by the Security Council, General Assembly, or [the] International Court." 74 When in 2008 Colombia attacked FARC guerrilla camps across the border in Ecuador, none of the "principal organizations of the United Nations criticized the action; while the Organization of American States adopted a resolution declaring the Colombian raid to be a violation of Ecuador's sovereignty, the OAS 
stopped short of expressly condemning Colombia."75 Two judges of the International Court of Justice each stated in separate opinions in the 2005 case Armed Activities on the Territory of the Congo that if the ICJ still endorses a literal reading of Article 51, limiting self-defense to an attack by another state, then the ICJ is no longer consistent with either state practice or the practice of the Security Council. ${ }^{76}$

In other words, it is important not to see the U.S. on this point as some solitary outlier from other states. The gap, rather, lies with the influential, loose body of "soft-law" opinion-makers, activists, academics, and commentators. And the tension here is neither surprising nor necessarily unhealthy. The United States will always have a need to make these kinds of flexible decisions about national security. And the dynamic will always and forever be that middling state powers, emerging great powers, outright enemies, idealistic NGOs, United Nations functionaries, law professors and intellectuals, and other such actors will seek to leverage their influence by using the rhetoric of international law to constrain U.S. flexibility in exactly this regard.

With respect to international law, therefore, the U.S. justification for the legality of a particular targeted killing should focus on self-defense as the basis, irrespective of whether or not there is also an armed conflict under IHL underway that might provide a further basis. Conceding over time that targeted killing can be distinguished from extrajudicial execution only if it is part of an armed conflict under IHL will subject the United States to requirements that, in fact, it has not traditionally accepted as a matter of international law but will find difficult to reverse in circumstances in which the definition of an armed conflict under IHL has not been met. The U.S. will receive plenty of pushback just on the question of what constitutes its legitimate self-defense under international law in this area. It buys itself only additional constraints if it also allows the international law of self-defense to run together with the law governing the conduct of hostilities.

\section{American Domestic Regulation of Targeted Killing}

Modern U.S. statutory authority for non-law enforcement exercises of force by "intelligence" actors begins with the National Security Act of 1947 that created the CIA and granted it authority to engage in a wide variety of intelligence activities. The 1947 Act also authorized the performance of "additional services of common concern" and "such other functions and duties related to intelligence affecting the national security as the President or the National Security Council may direct." 77

The reference to "other functions and duties" — commonly termed the 'Fifth Function'is deliberately obscure. But as foreign relations legal scholar Phillip Trimble observes, the breadth of known incidents under the Fifth Function is sufficient to suggest that "the executive branch has interpreted the legislative mandate broadly and Congress has regularly acquiesced." 78 During the 1960 s, for example, these included assistance to overthrow governments in Iran and Guatemala; assistance in attempts to "assassinate leaders in Cuba, Chile, and Zaire;" support for "civil wars in Iraq and Laos;" and an 
"invasion of Cuba."79 Although one might characterize some number of these activities as having taken place as part of armed conflicts, the characterization would not apply to them all. In any case, the United States was not participating as a party to these conflicts where they existed. Whether rightly or wrongly, justly or unjustly, the United States has often used force, not under color of law enforcement or in the context of IHL armed conflicts to which the U.S. was a party, but instead under domestic statutory authority.

The point, for our purposes, is that legal or not under international law of self-defense, those early Cold War interventions were undertaken on an understanding that there was a valid basis in international and domestic law for uses of force apart from, and short of, war in an IHL sense. And, moreover, that these uses of force might be carried out by civilian agents, rather than regular armed forces, of the United States. Notwithstanding the reforms that have strengthened Congressional oversight and other watchdog functions over the past several decades, nothing in the basic statutory arrangement challenges this fundamental assumption that U.S. domestic law permits in certain circumstances the uses of force, including targeted killing, by civilian agents of the government in circumstances that implicate self-defense under international law but do not necessarily constitute an IHL armed conflict.

The domestic law governing the "intelligence community" changed dramatically in the 1970s, largely because these covert uses-of-force came to light and were found by many to be wrong, imprudent, unjust, or unjustified under claims of self-defense or imperative national security. Watergate-era congressional hearings in 1974 resulted, among other things, in funding restrictions on intelligence activities under the Hughes-Ryan Amendment to the Foreign Assistance Act of $1974 .^{80}$ This amendment, combined with the Intelligence Oversight Act of 1980, laid down the basic pattern of post-Watergate domestic law restrictions on "covert" actions, including those that involve the use or threat of use of force: ${ }^{81}$

- Intelligence agencies had to seek and receive a presidential finding before undertaking any such operation;

- the President had to be informed of it;

- the substantive standard for such actions was that "each such operation is important to the national security of the United States";

- the President had to report on each operation "in a timely fashion," although not necessarily in advance, to the intelligence committee of each house of Congress;

- Congress could express its will in current or future funding. ${ }^{82}$

In this statutory and regulatory arrangement for the conduct of intelligence activities, Congress left deliberately vague what constitutes an operation covered by the statute. The use of force is not explicitly mentioned at all, although it is unquestionably understood. The statute glosses over thorny U.S. domestic law issues of separation of powers. But while the fundamental constitutional issues, Michael Reisman notes, remain inconclusively resolved, there is no ambiguity on the authority to engage in covert action. "[I]f there was any doubt regarding the statutory basis for covert action, the Hughes-Ryan Amendment... and Intelligence Oversight Act of 1980 removed it." ${ }^{83}$ 
This regime contains no suggestion that these operations, insofar as they use force, legally can only take place as part of an armed conflict within the meaning of international humanitarian law. Indeed, the first statutory definition of "covert action" offered in 1991 in the Intelligence Authorization Act for Fiscal Year 1991, refers very obliquely to covert uses of force. "Covert action," under the statute, means activities to "influence political, economic, or military conditions abroad, where it is intended that the role of the United States Government will not be apparent or acknowledged publicly." It specifically does not include activities the "primary purpose of which is to acquire intelligence." ${ }^{" 84}$ Moreover, covert action is defined not to include either "traditional diplomatic or military activities or routine support to those activities...[or] traditional law enforcement activities conducted by United States Government law enforcement agencies or routine support to such activities..." ${ }^{95}$ It is an attempt to regulate and to require oversight of - including the possibility of Congress refusing to fund - covert actions, including such uses of force as the 1984 mining of Nicaraguan harbors, not to legislate them out of existence.

Moreover, reforms of intelligence actions in the past three decades have been overwhelmingly concerned with oversight particularly of peacetime (that is, not in an IHL armed conflict) covert uses of force-presumably because Congress was most concerned that peacetime operations would be less scrutinized than operations conducted as part of an acknowledged armed conflict in which the existence of the conflict was plain and the application of law of war standards was clear. Hence, the exception in the statute for "traditional" military activities, such as open, overt war. At this moment, an important intragovernmental debate is underway as to whether various Predator strikes in Pakistan constitute "covert" activities that, notwithstanding their connection to the ongoing war, are nonetheless covered by the statute, or whether instead they are part of the "traditional" activities of the military in conducting war. Whatever the correct answer, no one in that debate is questioning that the fundamental category is covert operations that might take place either in the context of an IHL armed conflict or else as part of an operation justified by the doctrine of self-defense.

\section{The U.S. Assassination Ban}

The American law that most closely addresses targeted killing outside of armed conflict is not a statute. In the Church committee hearings in Congress in the mid-1970s, the CIA's role in various assassination attempts in earlier years became public and a matter of widespread outrage. In the public uproar that followed, the Ford Administration issued an Executive Order banning U.S. government employees from engaging in or conspiring to engage in political assassination. ${ }^{86}$ This order was repeated in slightly varying language by President $\operatorname{Carter}^{87}$ — who unaccountably dropped the word "political" —and finally reissued in the form still in force today, Executive Order 12333 by President Reagan. The pertinent section reads: "No person employed by or acting on behalf of the United States Government shall engage in, or conspire to engage in, assassination." ${ }^{88}$ 
This brief sentence has occasioned considerable scholarship and other commentary, much of it learned and ingenious, intended to interpret and reinterpret the provision. The Executive Order, after all, provides no definition of assassination, and the materials collateral to the three versions of the order shed little if any authoritative light on what it is supposed to mean. The issue has been repeatedly on the table for the obvious reason that, interpreted as widely as it might be, Executive Order 12333 would appear to preclude the targeting of the head of a hostile state who was, for example, the commander in chief of enemy armed forces and otherwise a legal target. The order does not distinguish between wartime and peacetime either, between armed conflict governed by IHL targeting standards or anything else.

Commentators have suggested various ways of reading the ban. The Church committee was focused upon the shocking revelations of CIA participation in plots against foreign leaders in peacetime; "peacetime" was specifically mentioned by President Ford in suggesting contemporaneously his support for legislation banning assassination of foreign officials. A Congressional Research Service report suggests that "assassination may be viewed as an intentional killing of a targeted individual for political purposes." Many others, however, have argued, in part based on the focus of the Church committee hearings, that assassination as understood in American usage connotes attacks directed at political leaders - and terrorists are not political leaders. Still others have noted that the term carries a sense of covertness and treachery, and not merely surprise. And still others have argued that acts of self-defense-including armed conflict undertaken within the legal meaning of self-defense, and including surprise attacks as part of self-defense-are outside the scope of the assassination ban. The United States government has expressed official views, however. The view of Legal Adviser to the State Department under Reagan, Abraham Sofaer, for example, was that assassination was not merely a killing with a political motive or aimed against a political leader, but that it also independently had to be a "murder" in the first place. Sofaer noted that "virtually all available definitions of 'assassination' include the word 'murder'... a crime[;] that element is the most fundamental aspect of the assassination prohibition." Thus, under "no circumstances" should assassination be defined to include any otherwise "lawful homicide." ${ }^{\prime \prime 9}$ Unlawfulness, in the State Department view of the 1980s, and apparently not contravened by later pronouncements, is a necessary prior element of an assassination.

Actual U.S. state practice since the issuance of the Reagan order strongly supports a narrow reading of it, including the narrowing view that to violate the Executive Order, the homicide must have been independently unlawful. Not long after the issuance of the Executive Order, after all, President Reagan in 1986 ordered a retaliatory air strike against Libya. According to press accounts, and seeming to eschew locutions about attacking a military target that might merely collaterally include the Libyan president Muammar Qadaffi - the President said that the attack was aimed at Qadaffi personally, in order to try and kill him. ${ }^{90}$ The First Gulf War, and the more recent Iraq and Afghanistan wars all saw efforts at "decapitation" strikes aimed at the leadership of enemy regimes, for impeccable military reasons - but as well on humanitarian grounds that the leadership is a legitimate target in war and that killing a regime's leaders might bring war to a close 
without great loss of non-leadership life. ${ }^{91}$ These actions are all in the course of armed conflict governed by IHL - since they constituted state-to-state hostilities covered by the formal terms of Article 2 common to the Geneva Conventions, and in each case the political leadership were regarded without controversy as legitimate targets of attack. Predator strikes in Pakistan, Yemen, and other places where IHL might or might not apply to the use of force have not been considered by the former Bush Administration or the Obama Administration to contravene the order or to require its modification or revocation, supporting the view that they see it as narrow in the ways that Sofaer announced as U.S. policy in 1989.

The best reading of the Executive Order at this point in time is to say that, without further definition, it is a ban co-extensive with pre-existing U.S. obligations under international law. Sofaer suggests as much when he says that examination of international "laws of war also supports limiting the assassination prohibition to illegal killing"-but then carefully makes clear that illegal killing does not include the lawful exercise of the right of self-defense under international law. ${ }^{92}$ And, with respect to domestic law, assassination is a term of art referring to a form of already-illegal murder, gradually unfolding in U.S. state practice, ${ }^{93}$ but, in any event, not something that should be construed "in a manner that inhibits the lawful exercises of lethal force."

All that said, the assassination ban seems to operate as a principal analytic constraint on targeted killings outside of the context of IHL armed conflict. When government lawyers worry about the lawfulness of a proposed targeted killing, their concern seems not to be about the IHL definition of armed conflict. Rather, it appears to focus on whether the killing qualifies as an assassination or not. Recourse to the position of the State Department in 1989 urges that this focus is the wrong one. Moreover, embracing extra and unnecessary justifications to avoid the possibility that an exercise of lethal force might be characterized as an assassination under criteria that are far wider than the State Department's view of an already-illegal killing gradually weakens the position of the United States on targeting in self-defense.

\section{Pressure on the American Position}

To all of this, the Obama Administration might ask a resounding "So what?" These human rights and other issues might exist in some hypothetical counterterrorism campaign far in the future if some administration were prepared to sign on to readings of international law the United States has always rejected. But for now, in the fight against al Qaeda, we have the AUMF, and we don't accede to the more extravagant arguments of the international human rights community. The result is that targeted killings are governed by IHL. We are only using them when the conditions of self-defense have all been met. And those facts also conveniently get us around the assassination ban. Perhaps someone might raise some legal difficulty over operating in parts of Pakistan and over targeting parties not clearly related to al Qaeda. But practically, it all seems like the same "armed conflict." So whatever the problems that might exist legally tomorrow, we do not have a legal difficulty today. 
That even the Bush Administration always treated its targeted killings as the targeting of combatants covered by the AUMF in a war covered by IHL says something about the pressures the American legal structure faces from actors in the international legal community. Those pressures are unlikely to abate. For the current American view of its authority to conduct targeted killings, as described above, is barely more palatable to key elements of the international community than the one I advocate. What's more, seemingly innocuous changes in and acquiescence to various legal regimes and rules could end up undermining the American legal rationale for targeted killings. The United States, to cite only one example, would like to have a more productive engagement with the International Criminal Court; this would put a considerable premium on the definition of the crime of "aggression" in that tribunal.

Some of the long term international legal pressure turns on a fundamental difference in understanding concerning how international law works - a difference that sometimes has a strong effect on interpretive outcome. In the long-held American view, international law classically binds sovereign states through their consent, either contractually through explicit treaties or implicitly through their assent to gradually evolving customary law. By contrast, those seeking to constrain states or alter their behavior beyond their consent have an incentive to expand the canon of what is implicitly agreed to by states, and generally binding on all of them, in the form of this body of customary international law. ${ }^{95}$ Since custom is not limited to the explicit terms of a ratified treaty, it is open to expansive restatement, interpretation, and invention by a wide variety of actors, both governmental and non-governmental. Classically, customary law has been evidenced principally by the actual behavior of states - functioning to ensure that international law does not over time become a purely paper enterprise with terms departing further and further from what states actually do. What is not prohibited to states, however, is generally permissible for them. So on this view, the question of targeted killing is not whether it is affirmatively allowed, but instead whether some treaty provision, or some genuinely accepted customary rule, prohibits it.

These traditional underpinnings of international law are, however, contested in the contemporary world as the "ownership" of international law-who sets its terms, interprets its rules, determines its content and meaning - is no longer entirely in the hands of sovereign states. Other actors - international advocacy organizations, international tribunals, international organizations and their functionaries, professors and academics, middle-weight states that see international law as a means to constrain more powerful sovereign states - play a significant role in setting the terms of the meaning and interpretation of international law. And while it's easy now for the American administration to pretend these currents don't exist, they have a way of seeping in as real constraints on American practice.

The stakes are higher than American policymakers appear to realize - as even a cursory look back over the past few years should make plain. At the most overt level, there is the possibility of prosecution abroad based on a consensus view of international law that the United States rejects. No one who has watched the European eagerness to initiate 
criminal and civil proceedings against Israeli and American officials in ever-proliferating judicial forums can be entirely sanguine about a giant gulf between American and international understanding of a practice that the international law community regards as murder. ${ }^{96}$ The more aggressively the United States uses this instrument, the more glaring the gulf will become - until, in some jurisdiction, someone decides to assert the consensus view as operative law. Absent some aggressive effort to defend the American position, that magistrate or prosecutor will have the overwhelming weight of international legal opinion behind him.

But the problem for the United States is not limited to the possibility of criminal proceedings abroad. American courts themselves are far from immune to the influence of soft law development. Consider only the manner in which American detention policy has been affected by parallel currents of international law opinion imported into American law through Supreme Court opinions. Only seven years ago, an American administration took a "so what" attitude toward international law ferment over detention that was rather similar to the current consensus on targeted killings. International legal scholars, NGOs, international organizations, and most countries took a far more restrictive view of the detention authority residing in IHL - specifically with respect to the protections due to unlawful enemy combatants - than did the United States, which had quietly preserved but not fought aggressively for a different approach over the preceding decades. The Supreme Court, however, has now gone a considerable distance to bridge the gulf by insisting that at least a portion of the Geneva Conventions covers all detainees. Whatever one thinks of that judgment, it is a striking example of the capacity to impact American law of the sort of international legal developments we are now seeing with respect to targeted killing.

More broadly, there are hidden but important costs when the United States is perceived by the rest of the world to be acting illegally. For one thing, it limits the willingness and capacity of other countries to assist American efforts. Detention here again offers a striking example; virtually no other country has assisted in American detention operations since September 11 in large part because of concerns over its legality. The more heavily and aggressively the United States banks on a policy that a strong consensus regards as per se criminal, the more tension it can expect in efforts to garner other countries' and organizations' cooperation in counterterrorism efforts. Absent a strong effort to establish the legitimacy of current American practice, this too, over time, will push the United States away from it.

The Obama foreign policy team may assume that the world's goodwill toward the new administration means acceptance over time of these actions. That is surely mistaken. The admirable, if mistaken, views of international law scholars and the international law community on how human rights law should apply universally did not develop because Obama's predecessor was named Bush — and they won't melt in the face of affection for a popular new president. Over the long run, if the Obama Administration wants to continue to fight using more discriminating, precisely-targeted weapons instead of fullscale combat, it's going to have to confront this problem while it still has intellectual and legal maneuvering space. 


\section{Legitimate Concerns}

The concerns that underlie all of this international law ferment-chiefly, mistaken targeting decisions and excessive collateral damage - are real and substantial. A wholly justified worry about targeted killing, particularly as offered here, is that it is a defense of the practice without offering anything in the way of standards for its effective regulation. If Congress and the administration wish to maintain and defend the legitimacy of this category of violence and to demonstrate that it is not unlimited or unregulated and exists within bounds, the question of visible domestic standards requires attention. Indeed, the reach to situate this activity under the law of IHL armed conflict is, in its substance, a reach to standards of proportionality, discrimination in targeting, and minimizing collateral damage.

It would be a profound mistake, as I have argued, to formally adopt such standards on the mistaken view that they must apply as a matter of a particular regime of international law that has its own triggers for when it applies as a matter of law. Treating these standards as binding law for their own sake, rather than useful and appropriate policy standards, would be an unwelcome additional invitation to war crimes prosecutions by other states and international tribunals against those engaged in key missions.

The standards that do apply as a matter of binding customary law of self-defense are, as noted, necessity and proportionality, even applied to the conduct of self-defense operations. In seeking ways to operationalize those two legal requirements, it is highly relevant to look to IHL standards, even if they do not apply as law as such. The minimum proportionality calculation, for example, with respect to collateral damage should begin with the classic IHL formulation weighing military advantage against innocent third party damage, and certainly should not drop below that. These are areas in which existing standards developed in IHL are highly persuasive as a policy matter and in informing the content of customary law of the conduct of self-defense operations. Congress and the administration should move to address these valid concerns about substantive standards - yet without taking steps that offer an implied invitation for international bodies or other states to treat the activities as potential war crimes under their jurisdiction. The U.S. government should also recognize that its ability to sustain such programs over the long term depends in considerable part on keeping technology moving forward to greater discrimination in targeting - and that requires research and development.

The elephant in the room, so to speak, however, is the standard by which American forces select targets in the first place. This is the core objection to the whole practice, for example, raised by UN special rapporteurs and many others - on what basis does the U.S. conclude that this person is a terrorist? While the substantive standard governing conduct to evaluate a potential targeted killing in relation to innocent third party collateral damage is best drawn from standards in the law of IHL armed conflict, target selection in targeted killing is an intelligence matter. And although military intelligence has much to offer in 
the way of methodology, military law has much less so. Yet the intelligence community, for many reasons, has had only limited success in picking targets since $9 / 11$-although the quality of target selection in the current campaign of Predator strikes by the CIA in Pakistan has clearly gone up. Congress can impose more demands for information to the intelligence committees and greater monitoring of target selection either before or after an attack, but it faces great limits in doing more than that. Congress cannot make the intelligence judgments.

The concerns over targeted killings are not, of course, limited to targeting and collateral damage questions. Other states, particularly friendly and allied states, have excellent reason to view these policies with political alarm - quite apart from their abstract legal assessments of them. Britain, for example, has a certain number of radical imams who appear directly to influence their followers, among other things, to take up jihad in Pakistan and Afghanistan against the U.S. and NATO allies. ${ }^{97}$ In purely hypothetical terms, the U.S. might do well to target and kill them in Britain. While the U.S. is obviously not going to do that, it will target al Qaeda with Yemen's consent in Yemen, and there are circumstances in which it will target terrorist suspects without territorial state consent.

What we seek, that being the case, are policy standards that distinguish between two distinct, prototypical situations. On the one hand, policy should unashamedly permit the use of Predators and Hellfire missiles against the leadership of a terrorist organization under, for example, the following conditions: The group poses a grave threat to the United States; its leadership is safely ensconced in a failed state somewhere; a state of armed conflict within the meaning of IHL may or may not exist; seeking to obtain custody or extradition or other "ordinary" measures will not only be unavailing, it will tip off the targets; the administration has concluded that it cannot undertake another full scale military assault, least of all for the purpose of killing a discrete, small group of terrorists. This describes Afghanistan under the Taliban, of course, but it captures (as the Obama campaign correctly recognized) even more accurately Pakistan and its trajectory today, with all the policy unpleasantness that it implies.

On the other hand, we certainly want a rule that prohibits the 1978 "poisoned-tip umbrella" killing of Bulgarian defector Georgi Markov by Bulgarian State Security agents on the streets of London ${ }^{98}$ or the still-disputed account of the 2006 poisoning of former Russian FSB agent Alexander Litvinenko, also in London, by alleged Russian government agents. ${ }^{99}$ These latter cases would surely be covered by the assassination ban were they hypothetical U.S. operations, not to mention not remotely cases of "selfdefense" - though the cases of radical imams who are operationally part of al Qaeda conceivably might be. The distinction has to be more meaningful, obviously, than the mere assertion that it's different when our guys do it. The United States, moreover, presumably wants it known that its agents will not undertake targeted killings in the United Kingdom under any circumstances, even if they might in Somalia; there will also be a category of states where strategic ambiguity is preferred. Here a rule of international law will necessarily not avail us; because of the formal equality of states, international 
law rules will have great trouble separating the Britains from the Somalias. Yet that is precisely what policy as a practical, substantive matter requires.

But what, then, does separate them - besides, that is, the not irrelevant factors of power, friendship and alliance with the United States and its community of allies? The most obvious factor is that a failed state creates ungoverned territory in which terrorists can find haven. While that is the most obvious case, however, the truly ungoverned territory of a truly failed state is probably not the most dangerous with respect to the harboring of terrorist organizations; precisely because it is obviously ungoverned, objections to intervening there are fewer even by those who would ordinarily object. The most dangerous safe havens, rather, are not entirely failed states, but states which are functioning sufficiently to provide the levers of a state to terrorist organizations, either because the state is a fully functioning one that shares, ideologically or tactically, aims with the terrorists, or because the state is functioning sufficiently to provide both a buffer against outside pressure and a launching pad, but not sufficiently to prevent the disaggregation of important powers in favor of the terrorists. This latter description captures at least part of the complex situation of al Qaeda and the Taliban in Pakistan. These situations mark out the most important category of places in which the United States might see the value of targeted killing.

At the other extreme are liberal democracies functioning under the rule of law that permits the adjudication of legal claims such as the question of Russian agent involvement in the London incident. It is sometimes suggested that the genuinely "neutral" way of dividing places in which some form of forcible covert activity (usually speaking of abduction of an alleged terrorist) is acceptable from where it is not is the presence, first, of a functioning state. The difficulty with stopping there is that Iran is a functioning state, and for that very reason a successful sponsor of terrorist groups. Next, then, it is suggested that it must be a functioning state combined with the rule of law, by which extradition and other such claims can be openly and neutrally adjudicated. The difficulty is that it is possible to have a state with a reasonably neutral rule of law that is part of a system that is neither liberal nor democratic, and which is entirely sympathetic to the aims and open to the means of terrorism — not frequently, but certainly possible.

At some point, in other words, however much one might point to neutral criteria such as the rule of law, or quasi-universal criteria such as "liberal democracy," in the end they do not quite describe the dispositive factors. When it comes to the specific issue of terrorism, it comes down to whether a state (or a sufficiently powerful and independent part of it) is willing to give haven to enemies of the United States. That and the costs and risks of using covert force, including the risk of its becoming known, versus the benefits. ${ }^{100}$ There are indeed overwhelmingly principled reasons why the United States would not do such in London, but those principles are not completely neutral; they have also very much to do with the fact of the ideals and interests that the United States and the United Kingdom share.

Comity, therefore, is a powerful — if non-legal, non-law-based — argument against violent covert action, targeted killing, abduction, and similar acts. Indeed, it might well be the 
most powerful, or at least the most accurate, argument in assigning policy responses. But it is a calibrated argument, not a categorical one - an argument that operates on a sliding scale with respect to the community of nations: friends, allies, those who might cooperate under a carrot or stick, enemies, and territory only nominally governed. We should note as well that this is a matter that implicates not only state sovereignty-which we directly challenge when we engage in a targeted killing without the host state's consent - but also human rights. All things equal, the best and proper way to proceed is through mechanisms of the rule of law: presentation of evidence to a neutral tribunal and transparent mechanisms of justice. We prefer this both for principled reasons and for practical ones: intelligence methods are very far from infallible. But things are not always equal when it comes to preventing terrorism, and in that regard not all states are equal, either.

But it would lead the reader astray not to acknowledge that of anything in this chapter, the proposal of a rule of comity for sovereign states in which the United States would undertake targeted killing and sovereign states in which it would not is purely a proposal of policy - and the least compatible with widely held assumptions of the international law community insofar as it contravenes the basic assumption of the sovereign equality of states. On the other hand, it has the virtue of realist clarity, how the United States behaves, and how other states behave. But, to reiterate, this is all hypothesizing about policy, not law.

\section{What Should Congress Do?}

Does this analysis offer any practical policy prescriptions for Congress and the administration? The problem is not so much a need for new legislation to create new structures or new policies. The legislative category in which many instances of targeted killing might take place in the future already exists. The task for Congress and the administration, rather, is instead to preserve a category that is likely to be put under pressure in the future and, indeed, is already seen by many as a legal non-starter under international law.

Before addressing what Congress should do in this regard, we might ask from a strictly strategic political standpoint whether, given that the Obama Administration is committed to this policy anyway, whether it is politically prudent to draw public attention to the issue at all. Israeli officials might be threatened with legal action in Spain; but so far no important actor has shown an appetite for taking on the Obama Administration. Perhaps it is better to let sleeping political dogs lie.

These questions require difficult political calculations. However, the sources cited above suggest that even if no one is quite prepared at this moment to take on the Obama Administration on targeted killing, the intellectual and legal pieces of the challenge are already set up and on the table. Having asserted certain positions concerning human rights law and its application and the United States having unthinkingly abandoned its self-defense rationale for its policy, the play can be made at any time - at some later time 
in the Obama Administration or in the next Republican administration, prying apart the "American" position to create a de facto alliance among Democrats and Europeans and thereby undermining the ability of the United States to craft a unified American security strategy. ${ }^{101}$ The United States would be best served if the Obama Administration did that exceedingly rare thing in international law and diplomacy: Getting the United States out in front of the issue by making plain the American position, rather than merely reacting in surprise when its sovereign prerogatives are challenged by the international soft-law community.

The deeper issue here is not merely a strategic and political one about targeted killing and drones but goes to the very grave policy question of whether it is time to move beyond the careful ambiguity of the CIA's authorizing statute in referring to covert uses of force under the doctrines of vital national interest and self-defense. Is it time to abandon strategic ambiguity with regards to the Fifth Function and assert the right to use force in self-defense and yet in "peacetime" - that is, outside of the specific context of an armed conflict within the meaning of international humanitarian law? Quite possibly, the strategic ambiguity, in a world in which secrecy is more and more difficult, and in the general fragmentation of voice and ownership of international law, has lost its raison d'etre. This is a larger question than the one undertaken here, but on a range of issues including covert action, interrogation techniques, detention policy, and others, a general approach of overt legislation that removes ambiguity is to be preferred.

The single most important role for Congress to play in addressing targeted killings, therefore, is the open, unapologetic, plain insistence that the American understanding of international law on this issue of self-defense is legitimate. The assertion, that is, that the United States sees its conduct as permissible for itself and for others. And it is the putting of congressional strength behind the official statements of the executive branch as the opinio juris of the United States, its authoritative view of what international law is on this subject. If this statement seems peculiar, that is because the task - as fundamental as it is - remains unfortunately poorly understood.

Yet if it is really a matter of political consensus between Left and Right that targeted killing is a tool of choice for the United States in confronting its non-state enemies, then this is an essential task for Congress to play in support of the Obama Administration as it seeks to speak with a single voice for the United States to the rest of the world. The Congress needs to backstop the administration in asserting to the rest of the worldincluding to its own judiciary - how the United States understands international law regarding targeted killing. And it needs to make an unapologetic assertion that its views, while not dispositive or binding on others, carry international authority to an extent that relatively few others do - even in our emerging multi-polar world. International law traditionally, after all, accepts that states with particular interests, power, and impact in the world, carry more weight in particular matters than other states. The American view of maritime law matters more than does landlocked Bolivia's. American views on international security law, as the core global provider of security, matter more than do those of Argentina, Germany or, for that matter, NGOs or academic commentators. But it has to speak - and speak loudly - if it wishes to be heard. It is an enormously important 
instance of the need for the United States to re-take "ownership" of international lawnot as its arbiter, nor as the superpower alone, but as a very powerful, very important, and very legitimate sovereign state.

Intellectually, continuing to squeeze all forms and instances of targeted killing by standoff platform under the law of IHL armed conflict is probably not the most analytically compelling way to proceed. It is certainly not a practical long-term approach. Not everyone who is an intuitively legitimate target from the standpoint of self-defense or vital national security, after all, will be already part of an armed conflict or combatant in the strict IHL sense. Requiring that we use such IHL concepts for a quite different category is likely to have the deleterious effect of deforming the laws of war, over the long term - starting, for example, with the idea of a "global war," which is itself a certain deformation of the IHL concept of hostilities and armed conflict.

The most intellectually honest approach would be to begin from the category of selfdefense as the U.S. has traditionally understood it in international law and then defend the category as it currently exists in U.S. domestic statutory law for the intelligence community - that as long as a targeted killing legitimately meets the legal criteria of selfdefense, it can be lawful to target people who might not be, under the strict law of IHL armed conflict, combatants. Needless to say, this for the moment appears to be a political non-starter - as evidenced by the fact that even the Bush Administration seems never to have engaged in a targeted killing of someone it conceded was not, legally speaking, a combatant under IHL. In practical terms, the space Congress needs to defend is targeted killing within the broad vision of armed conflict as defined by the traditional American interpretations of the inherent right of self defense.

Specifically, Congress and the Obama Administration should find ways, formal and informal, of asserting that as long as targeted killings satisfy standards of self-defense, the United States regards them as lawful in the sense of not per se illegal; and that these operations can and will be carried out as part of essential counterterrorism under existing domestic legal authority granted to the intelligence community and the CIA. One way to do this is by adding language to the basic CIA statute specifically providing what is already implicit: that the power to carry out its "other" functions apply in peacetime and is not limited to circumstances of internationally recognized IHL armed conflict. ${ }^{102}$ In so doing, Congress should refer in the statute to the exercise of vital national security interests as including the inherent right of self-defense as the United States interprets that legal concept. There is value in tying such instances of uses of force under domestic law directly to the assertion of a right of self-defense under international law in order to make clear its basis and that it is different from IHL armed conflict.

The independent legal existence of the category of intelligence agency uses of force as lawful self-defense, including targeted killing, should also be stated - frequently-in hearings, in official statements of the administration, by the CIA, the Justice Department, and the State Department as the opinio juris of the United States. This policy can be expressed by Congress in statements accompanying appropriations bills and other legislative pronouncements. Given the extent to which such issues increasingly appear in 
U.S. domestic litigation, such as cases brought under the Alien Tort Statute, the Department of Justice needs a standing policy vigorously to defend this position as the foreign policy of the United States, assented to by the political branches, to which the judiciary should pay due deference.

Most importantly, Congress should reiterate and endorse two things regarding the ICCPR. The first is the long-standing U.S. position that the ICCPR does not apply extraterritorially. The second is that IHL substitutes for, and displaces, any more general human rights regimes, including the ICCPR, in armed conflict within the meaning of IHL. This is important because so much of the international law community now takes it as a matter of course both that the ICCPR does apply extraterritorially and that it continues to apply in the course of an IHL armed conflict. As a consequence, as we have seen, virtually any targeted killing can be easily characterized as an extrajudicial execution - and the agents who carry it out, whether civilian or military, might at some point be threatened with indictment in some jurisdiction or international tribunal for an international crime. If Congress does not want that to happen, it needs to push back against the premise that the ICCPR has anything to say about American conduct of such operations.

Even as it defends targeted killings against those who would simply treat the category as having disappeared all but entirely under international law, Congress and the administration need to offer standards to regulate the practice of targeted killing. This is hard. With respect to domestic law, proposals to create a comprehensive charter for the CIA have come and gone without fruition with regularity over the decades. ${ }^{103}$ The reason they do not succeed is that discretion is at the heart of the intelligence agency action agenda. Likewise, strategic deniability and the tacit collective action game among the great powers to acquiesce in this category so long as it is not celebrated as such and remains within a set of loose and unstated bounds both conspire to keep the rules unstated or, at least, stated vaguely. The same is true with respect to the specific question of targeted killing; there is no comprehensive charter that can be written and yet be effective.

There are, however, areas in which regulatory structure can be given - and should be, in order that the law not be merely a blank check. We start from necessity and proportionality in the conduct of self-defense operations. None of this will satisfy those for whom the category is morally wrong and legally impermissible as such - but for those for whom approval is possible in principle and yet look for the devil in the details, important aspects of regulatory control would include the two basic issues in targeted killing: the identification of a target (is this who we say it is?) and the minimizing of collateral damage to innocent third parties. Congress should therefore instruct the administration and the CIA to brief the intelligence committees as to the mechanisms used to make targeting selection decisions - not just in the case of Predator campaigns undertaken as part of the ongoing conflict in Afghanistan extending over to Pakistan, but also its protocols for determining targets outside of the existing conflict zones and armed conflict at all, which is to say, any targeted killing. In the same vein, Congress can instruct the CIA in hearings, in briefings to the intelligence committees, and in other 
forums that it expects to be informed as to protocols the CIA would apply in targeted killing situations outside of armed conflict zones to ensure minimal collateral damage, respect for proportionality, and discrimination in targeting - and to ensure that the CIA is committed to application of the substance of the standard law of war targeting considerations regarding protection of innocents. At a minimum, those collateral damage protocols should adopt those used in IHL - although in many instances, the appropriate level of caution to protect innocent civilians might well be higher than that required on the conventional battlefield. Standards drawn from IHL should be a policy minimum, not a maximum.

Congress should also consider instructing the CIA to develop criteria, secret or otherwise, for determining - perhaps subject to revision by Congress - what countries among U.S. friends and allies would not be places where the United States would consider undertaking targeted killing under any circumstances. Of anything said in this chapter, perhaps the most jarring to the international lawyer is the claim that the U.S. might need to distinguish as a matter of informal policy among states in which it would never contemplate a targeted killing and the states in which circumstances might make it necessary, with or without consent. Of course, such a distinction lies at the back of every political calculation of targeted killing, the same as calculations of friends and foes and those in-between. Yet this proposition cannot really be expressed as a matter of international law as such, because international law begins from the sovereign equality of states. This proposal takes a distinctly realist tack and breaks them down into friends, enemies, places where the rule of law obtains, places where it does not, and other such distinguishing criteria.

Congress could engage in this thoroughly political exercise by, for example, asking for hearings in which the administration would be invited to offer the criteria under which state sovereignty might be ignored and a targeted killing undertaken. Congress could instruct the administration to provide private assurances, and make the discussion of who and why a matter of intelligence oversight briefings. It is an idea that has costs and benefits, to be sure, and is only recommended, if by anything, on the virtue of realism.

Finally, Congress should greatly beef up the level of briefings and information provided to the intelligence committees and should review the issue of oversight of covert and clandestine operations and determine whether those mechanisms of oversight are sufficiently robust and contemporaneous. At least upon consideration of the controversies now emerging over briefings to Congressional oversight committees regarding interrogation, they are almost certainly not sufficient. The point about briefings to Congress is partly to allow it to exercise its democratic role as the people's representatives; just as important, however, is that such mechanisms ensure, if properly and thoroughly carried out and documented, that the Congress has either acquiesced in an executive decision or taken steps positively to object. Any administration should want to ensure that it has plainly and fully informed the intelligence committees so that the accountability and burden of making very difficult decisions about targeted killing are shared across the political branches of government. So there's a mutual advantage here. Moreover, there is room to consider forms of public reporting after the fact in some 
fashion to ensure that the public can know what actions have been taken. A regime of violent covert action based around pure secrecy and executive discretion is a recipe for indictments. The political branches should be forced into joint accountability. If targeted killings are really to become a tool of choice for certain types of counterterrorism, our oversight mechanisms need to reflect their new importance.

\section{Conclusion}

The ultimate lesson for Congress and the Obama Administration about targeted killings is "Use it or lose it." This is as true of its legal rationale as it is of the tool itself. Targeted killings conducted from standoff platforms, with improving technologies in surveillance and targeting, are a vital strategic, but also humanitarian, tool in long-term counterterrorism. War will always be important as an option; so will the tools of law enforcement, as well as all the other non-force aspects of intelligence work: diplomacy and coordination with friends and allies. But the long-standing legal authority to use force covertly, as part of the writ of the intelligence community, remains a crucial tool-one the new administration will need and evidently knows it will need. So will administrations beyond it.

Although the U.S. is in a war, in its view, with al Qaeda, much of the world does not accept this premise and the threat from transnational terrorism will not, in any event, forever be with al Qaeda. Even within the world of jihadist transnational violence, al Qaeda is gradually becoming a notional enemy. This is a popular notion with some as a meme by which to announce that the threat is past or overrated; that is not my intent here at all. Rather, I am concerned to ensure that we do not tie our hands needlessly tomorrow by assuming that the nature of the threat and the specific legal rationale offered to address it will always be the same. Transnational jihadist networks are indeed becoming more diffuse, less and less directly tied in a "corporate" sense to al Qaeda. They are inspired by it, perhaps, and driven by a shared ideology, but not under its command, control, active direction, or other indicia of affiliation in an ordinary sense. ${ }^{104}$ Terrorism by ideological affinity and loose network is likely to become more, rather than less, the norm into the future. The death of Osama bin Laden and his top aides by Predator strike tomorrow would alter national security counterterrorism calculations rather less than we might all hope. As new terrorist enemies emerge, so long as they are "jihadist" in character, we might continue referring to them as "affiliated" with al Qaeda and therefore cobelligerent. But the label will eventually become a mere legalism in order to bring them under the umbrella of an AUMF passed after September 11. Looking even further into the future, terrorism will not always be about something plausibly tied to September 11 or al Qaeda at all. Circumstances alone, in other words, will put enormous pressure onand ultimately render obsolete - the legal framework we currently employ to justify these operations.

What we can do is to insist on defining armed conflict self-defense broadly enough, and human rights law narrowly enough — as the United States has traditionally done- to avoid exacerbating the problem and making it acute sooner, or even immediately. 
Ideology and ideas matter in shaping policy, especially at the intersection of international realpolitik, diplomacy, and law. Thus, I have made frequent reference to a loose community of interpretation, formation, deployment, and, really, "ownership" of international law. Such "ownership" matters too. We stand at a curious moment in which the strategic trend is toward reliance upon targeted killing; and within broad U.S. political circles even across party lines, a political trend toward legitimization; and yet the international legal trend is also severely and sharply to contain it within a narrow conception of either the law of armed conflict under IHL or human rights and law enforcement, rather than its traditional conception as self-defense in international law and regulation as covert action under domestic intelligence law. Many in the world of ideas and policy have already concluded that targeted killing as a category, even if proffered as self-defense, is unacceptable and indeed all but per se illegal. If the United States wishes to preserve its traditional powers and practices in this area, it had better assert them. Else it will find that as a practical matter they have dissipated through desuetude. 


\section{Notes}

${ }^{1}$ Barack Obama, "The American Promise" (speech, Democratic National Convention, Denver, CO, August 28, 2008).

${ }^{2}$ Barack Obama, "The War We Need to Win" (speech, Woodrow Wilson International Center for Scholars, Washington, DC, August 1, 2007).

${ }^{3}$ Karen DeYoung, "Obama Tends Toward Mainstream on Foreign Policy," Washington Post, March 3, 2008, A07; full text of questionnaire responses available at $\mathrm{http}: / /$ www.themorningleader.lk/20080611/interviews.html.

${ }^{4}$ R. Jeffrey Smith, Candace Rondeaux and Joby Warrick, "2 U.S. Airstrikes Offer a Concrete Sign of Obama's Pakistan Policy," Washington Post, January 24, 2009, A01.

${ }^{5}$ See Mark Mazzetti and David E. Sanger, "Obama Expands Missile Strikes inside Pakistan," New York Times, February 21, 2009, A1; Karen DeYoung and Joby Warrick, "Drone Attacks inside Pakistan Will Continue, CIA Chief Says," Washington Post, February 26, 2009, A10; David E. Sanger and Eric Schmitt, "U.S. Weighs Taliban Strike into Pakistan," New York Times, March 18, 2009, A1; Pir Zubair Shah, "Missile Strike Kills 4 in Pakistan," New York Times, March 16, 2009; Jay Solomon, Siobhan Gorman and Matthew Rosenberg, "U.S. Plans New Drone Attacks in Pakistan," Wall Street Journal, March 26, 2009; Pir Zubair Shah and Alan Cowell, "Missile Strike Said to Kill 10 in Pakistan," New York Times, April 1, 2009, A10; Robert Birsel, "U.S. Missile Kills 13 in Pakistan," Reuters, April 4, 2009; Eric Schmitt and Christopher Drew, "More Drone Attacks in Pakistan Planned," New York Times, April 6, 2009, A15; Nahal Toosi, "Suspected U.S. Missile Kills 3 in Northwest Pakistan," Associated Press, April 8, 2009; Jane Perlez, "Pakistan Rehearses Its Two-Step on Airstrikes," New York Times, April 16, 2009, A10.

${ }^{6}$ See Habibullah Khan and Nick Schifrin, "Allegations that CIA Predator Drones Have Bases in Pakistan," $A B C$ News, February 23, 2009, available at

http://abcnews.go.com/International/story?id=6938365\&page=1. See also Pir Zubair Shah, "U.S. Airstrike Kills 21 in Pakistan," New York Times, March 14, 2009, A8; Simon-Cameron Moore, "U.S. Missile Strike in Pakistan Hit al Qaeda Nest," Reuters, January 31, 2008.

${ }^{7}$ Authorization for Use of Military Force, Public Law 107-40, 107th Cong., 1st sess. (September 18, 2001), $\S 2(\mathrm{a})$.

${ }^{8}$ See, e.g., Mark Sageman, Leaderless Jihad: Terror Networks in the Twenty-First Century (Philadelphia:

University of Pennsylvania Press, 2008).

${ }^{9}$ National Security Act of 1947, 50 U.S.C. 401.

${ }^{10}$ See Monica Hakimi, International Standards for Detaining Terrorism Suspects: Moving Beyond the Armed Conflict-Criminal Divide, 40 CASE W. RES. J. INT'L L. 593, 601-10 (2009), addressing the debate of criminal law or armed conflict law within the treatment of suspected terrorists; Davis Brown, Use of Force Against Terrorism After September 11th: State Responsibility, Self-Defense, and Other Responses, 11 CARDOZO J. INT'L \& COMP. L. 1, 18-26 (2003); Derek Jinks, September 11 and the Laws of War, 28 YALE J. INT'L L. 1 (2003).

${ }^{11}$ The implications of terrorists who are at once "criminals" and "enemies" is discussed in Kenneth Anderson, What Do We Do with bin Laden and al Qaeda Terrorists? A Qualified Defense of Military Commissions and the United States Policy on Detainees at Guantanamo Bay Naval Base, 25 HARV. J. L. \& PUB. POL'Y 593 (2002).

${ }^{12}$ The differences between police work and war is discussed in Kenneth Anderson, "Law, Language and Terror: Policemen or Soldiers? The Dangers of Misunderstanding the Threat to America (Commentary on 9-11)," Times Literary Supplement (September 21, 2001); Kenneth Anderson, "Remarks on Literature and International Law" (speech, American Society of International Law, Washington, DC, April 10, 1997).

${ }^{13}$ See Richard A. Clarke, Against All Enemies: Inside America's War on Terror (New York: Free Press, 2004), 54-61. See also Derek Chollet and James Goldgeier, America Between the Wars: From 11/9 to 9/11 (New York: PublicAffairs, 2008), 8-13.

${ }^{14}$ Philip Bobbitt, Terror and Consent: The Wars of the Twenty-First Century (New York: Penguin Books, 2008).

${ }^{15}$ Talk of a "third way" in counterterrorism risks conveying a deeply erroneous impression, however, in two regards. One is that it is a sort of "kinder, gentler" counterterrorism, whereas (as intended here) it embraces fully uses of force as part of its methods. A second is that it replaces the other two, whereas 
instead it completes the picture of counterterrorism, intelligence activities taking place alongside large scale, overt war and criminal law enforcement, as appropriate to the circumstances. See Kenneth Anderson and Elisa Massimino, "The Cost of Confusion: Resolving Ambiguities in Detainee Treatment," in Bridging the Foreign Policy Divide, eds. Derek Chollet, Tod Lindberg and David Shorr (New York: Routledge, 2008).

16 "Covert" activities has a statutory definition that sets it apart from the ordinary usage intended in this statement; we come to that statutory definition later in the discussion, but in general the statutory definition includes not only officially unacknowledged use of force, but any unacknowledged activity by the government or its agents to attempt to influence the policies of a foreign government —including, for example, unacknowledged propaganda or public relations, information campaigns and other things that are entirely unrelated to use of force.

17 Jack L. Goldsmith, The Terror Presidency: Law and Judgment Inside the Bush Administration (New York: W.W. Norton and Company, 2007), 177-83. Under the Obama Administration, the terms "global war on terror," "the long war," and others are to be replaced by "Overseas Contingency Operation," at least for the moment. See, e.g., Al Kamen, "End of the Global War on Terror," in "44: The Obama Presidency," Washington Post, March 23, 2009 , http://voices.washingtonpost.com/44/2009/03/23/the_end_of_the_global_war_on_t.html?hpid=news-colblog.

${ }_{18}^{18}$ See, e.g., Solomon, Gorman and Rosenberg, "New Drone Attacks," note 5 above.

${ }^{19}$ Barack Obama, "A New Strategy for a New World" (speech, Ronald Reagan Building, Washington, DC, July 28, 2008), indicating a need for "more Predator Drones" in the U.S. fight against al Qaeda.

${ }^{20}$ Graham Allison and John Deutch, "The Real Afghan Issue is Pakistan," Wall Street Journal, March 30, 2009, A23.

${ }^{21}$ Doyle McManus, "U.S. Drone Attacks in Pakistan Backfiring, Congress Told," Los Angeles Times, May 3, 2009.

${ }^{22}$ Allison and Deutch, "The Real Afghan Issue," note 20 above.

${ }^{23}$ See Archer Jones, The Art of War in Western World, (Champaign, IL: University of Illinois Press, 2000), 83-86.

${ }^{24}$ United States Department of the Army, U.S. Army/Marine Corps Counterinsurgency Field Manual: U.S. Army Field Manual no. 3-24: Marine Corps Warfighting Publication no. 3-33-5 (Chicago: University of Chicago Press, 2007), I-85 through I-90.

${ }^{25}$ I emphasize here transnational terrorists, such as the leadership of al Qaeda, bin Laden and those at the top of his organization, rather than groups that organize and undertake fighting directly in theatres of war, such as al Qaeda in Iraq.

${ }^{26}$ Matthew C. Waxman, Detention as Targeting: Standards of Certainty and Detention of Suspected Terrorists, 108 CoLuM. L. REV. 1365, 1401-02 (2008).

${ }^{27}$ Benjamin Wittes, Law and the Long War: The Future of Justice in the Age of Terror (New York: Penguin Press, 2008), 183.

${ }^{28}$ Much of this criticism is summed up in P.W. Singer, Wired for War: The Robotics Revolution and Conflict in the 21st Century (New York: Penguin Press, 2009).

${ }^{29}$ James Der Derian, quoted in P.W. Singer, "Robots at War," Wilson Quarterly (Winter 2009): 47.

${ }^{30}$ Saeed Shah, "Anger in Pakistan at U.S. Plan to Expand Drone Attacks," The Guardian, March 19, 2009. See also Jane Perlez, "Pakistan's Military Chief Criticizes U.S. Over a Raid," New York Times, September $10,2008$.

${ }^{31}$ The objection is actually a very old one, stretching back at least to the founding of the International Committee of the Red Cross in the mid-19th century. Florence Nightingale, for example - though she later became a firm supporter of the Red Cross movement - wrote in response to the call for a Red Cross Society that "such a Society...would relieve (governments) of responsibilities which really belong to them....and being relieved of which would make war more easy." Kenneth Anderson, "First in the Field: The Unique Mission and Legitimacy of the Red Cross," Times Literary Supplement (July 31, 1998).

${ }^{32}$ Singer, "Robots at War," 47.

${ }^{33}$ P.W. Singer was also an advisor to the Obama campaign on military and security matters, so perhaps the critique offered by his book will have greater sway than here suggested. 
${ }^{34}$ Political scientist Charli Carpenter correctly points out that this analysis creates an artificial binary between what is termed here 'full-scale' war and targeted killing, whereas the menu for the use of force offers many choices in-between. Charli Carpenter, e-mail message to author, March 19, 2009. This is true and important, but as a pure policy matter at this point in the Obama administration, and for whatever it is worth, my personal conversations with Obama staffers suggest that it is today a binary choice- the administration, for many obvious reasons, wants to avoid any possible on-the-ground engagements to which the United States is not already committed. Circumstances can always force an administration's hand, of course, and it is never inconceivable that events could force it with respect to Iran or North Korea. But my informal conversations suggest, entirely unsurprisingly, that the administration seeks to avoid any new engagements. The only one that was suggested as a new form of engagement was stronger activity as part of the multilateral, Security Council authorized, anti-piracy measures off the coast of Somalia - and even there only on the clear understanding that there would not be a U.S. presence on the ground. In that case, simply as policy practicality, the choices are binary, and drone air strikes look appealing where force must be used. My thanks to Professor Carpenter for this comment and others; she is not responsible for anything said here, particularly given her strong disagreement with the normative thrust of this entire discussion.

${ }^{35}$ Referring, of course, to overt clashes between Soviet and NATO armies and leaving aside the many proxy wars that each fostered instead.

${ }^{36}$ The strategic situation in that case is somewhat akin to the problem of the United States in the early Cold War, when over-reliance upon nuclear deterrence without the tools for intermediate non-nuclear responses tied the hands of the United States, because the actual confrontations were serious, but not enough to warrant nuclear war.

${ }^{37}$ Various writers have proposed different definitions, e.g.: "Targeted killing: the intentional slaying of a specific individual or group of individuals undertaken with explicit governmental approval." Maj. Matthew J. Machon, Targeted Killing as an Element of U.S. Foreign Policy in the War on Terror (Fort Leavenworth, KS: School of Advanced Military Studies, 2006), 20.

${ }^{38}$ The standard reference work on targeted killing and law is Nils Melzer, Targeted Killing in International Law (New York: Oxford University Press, 2008). It is a marvelous work of scholarship, more comprehensive than any existing source, by a senior ICRC legal advisor. Despite its depth of scholarship and unpolemical language, it is something of an advocacy brief, however. It is difficult to see any circumstances under which Melzer would accept outcomes not congenial to his prior legal views and, indeed, there is very little in the book that does more than note U.S. legal objections to some of the book's core positions and then reject them, without ever suggesting that they might have merit, or at least constitute a defensible alternative view. It is in this sense both the indispensable book on the subject, one which no researcher on this subject can do without - and yet, under the surface of the extraordinary scholarship, a relentless brief to a particular advocacy end. Melzer discusses all aspects of the topic, including a discussion — quite unusual, as the subject is often skipped over, just as I do here - of law enforcement uses of targeted killing. See ibid., 222-239.

${ }^{39}$ See, e.g., Micah Zenko, "Predator Strikes are Not the Answer, Council on Foreign Relations," The Guardian, March 19, 2009.

${ }^{40}$ Mark Osiel, The End of Reciprocity: Terror, Torture, and the Law of War (New York: Cambridge University Press, 2009), n. 102, 586; these commentators include, for example, Rosa Ehrenreich Brooks, currently a senior advisor in the Department of Defense. See Rosa Ehrenreich Brooks, War Everywhere: Rights, National Security Law, and the Law of Armed Conflict in the Age of Terror, 153 U. PENN. L. REV. 675, 756 (2003).

${ }^{41}$ Gary Solis, "Targeted Killing and the Law of Armed Conflict," Naval War College Review 60 (Spring 2007): 127, 135.

${ }^{42}$ Analysis begins with article 2 common to the Geneva Conventions. It has sometimes been summarized as saying that international humanitarian law is applicable in international armed conflicts "whenever any difference arises leading to the use of armed forces between the militaries of two states." Derek Jinks, "The Temporal Scope of Application of International Humanitarian Law in Contemporary Conflicts," background paper, International Humanitarian Law Research Initiative, Harvard Program on Humanitarian Policy and Conflict Research, January 2003, 3. However, it bears emphasizing that "use" of armed forces in interstate armed conflict is more than, for example, merely their appearance at the border in a time of 
tension - it refers to actual engagements between armed forces of states. The Tadic decision of the ICTY Trial Chamber (Prosecutor v. Dusko Tadic, no. IT-94-1-T, Opinion and Judgment, May 7, 1998) thus expresses a standard that is overly broad in stating that an "armed conflict exists whenever there is a resort to armed forces between States," because "resort to armed forces" is susceptible of readings lacking the actual armed engagement between armed forces. The lack of a common definition of armed conflicts makes the threshold for application of international humanitarian law to internal conflicts much more difficult to resolve and highly fact-dependent. Jinks, "Temporal Scope," 3-4.

${ }^{43}$ To use slightly more technical language, although still not as fully as a lawyer would put it: We therefore distinguish the jus in bello meaning of armed conflict from that under jus ad bellum, the legal question of the resort to force. We come later to the discussion of 'self-defense' under international law and its connection to targeted killing, but for now we need to note that armed conflict is often used in the sense of the legal regime governing resort to force-viz. the UN Charter and customary international law. The Charter does not actually use the term 'armed conflict,' referring instead to 'international peace and security,' 'aggression,' 'self-defense' and 'armed attack.' The emphasis of the Charter terms is what one would expect in provisions focused upon the resort to force-the beginning of conflict. Armed conflict, by contrast, is a term that conveys a greater sense of ongoing conflict, which is what one would expect in connection with the conduct of fighting. Armed conflict is thus a term somewhat more closely associated with jus in bello and conducts questions of international humanitarian law; the Charter does not use traditional terms associated with the customary law of jus ad bellum, such as belligerency.

However, 'armed conflict' is also a term used frequently with respect to each body of law, without necessarily a precise legal genealogy attached. Why does this matter of apparently mere nomenclature matter? Because the triggering standards for what constitutes an armed conflict and, hence, the substantive rules under each regime are different. International humanitarian law makes one kind of assessment; the Charter, looking to resort to force rules, refers to breaches of international peace and security, aggression and violations of territorial integrity of a state, among other things. Self-defense, under the Charter and customary international law, has it own standards - many of which are highly contested. The term 'armed conflict' is often used for one or another, but the standards and legal consequences can differ. In traditional state-to-state conflicts, the distinction typically might not make very much difference-but precisely in circumstances involving non-state fighters acting transnationally, the distinctions might indeed matter. ${ }^{44}$ Osiel, The End of Reciprocity, 407, n. 4.

${ }^{45}$ Nils Melzer, Targeted Killing, note 38 above.

${ }^{46}$ Ibid., 243. It is clear from the book's text that Melzer intends "hostilities" in the sense of an armed conflict under international humanitarian law.

${ }^{47}$ Sean D. Murphy, "The International Legality of U.S. Military Cross-Border Operations from Afghanistan into Pakistan," U.S. Naval War College International Law Studies 85 (forthcoming 2009): manuscript at 2, on file with author. I am grateful to Professor Murphy for sharing an advance draft of this paper with me and allowing me to cite to it.

48 "International Covenant on Civil and Political Rights," 999 U.N.T.S. 171, March 23, 1976, United States Treaties and Other International Agreements.

${ }^{49}$ John Quigley, The International Covenant on Civil and Political Rights and the Supremacy Clause, 42 DEPAUL L. REV. 1287, 1287-88 (1993), describing the background and history of the ICCPR.

50 "International Covenant on Civil and Political Rights," 171, art. 6.

${ }^{51}$ See, e.g., Chrissy Fox, Implications of the United States Reservations and Non-Self Executing Declaration to the ICCPR for Capital Offenders and Foreign Relations, 11 TUL. J. COMP. \& INT'L L. 303 (2003).

${ }^{52}$ Ibid., 322-323, expressing international criticism on U.S. refusal to budge on certain ICCPR provisions.

${ }^{53}$ See U.S. Department of State, Second and Third Periodic Report of the United States of America to the UN Committee on Human Rights Concerning the International Covenant on Civil and Political Rights, Annex I, October 21, 2005; Matthew Waxman, statement before the UN Human Rights Committee, July 17, 2006: "In addition, it is the long-standing view of the United States that the Covenant by its very terms does not apply outside of the territory of a State Party."

${ }^{54}$ See Inter-American Commission on Human Rights, "Report Colombia 1999," ch. IV, § 11; InterAmerican Commission on Human Rights, "Guantanamo Detainees Case (Precautionary Measures); Juan E. 
Mendez to attorneys for those requesting provisional measures," letter, 13 March 2002, quoting letter notifying United States of the imposition of provisional measures, available at http://www.ccr-ny.org/v2/legal/september_11th/docs/3-1302\%20IACHRAdoptionofPrecautionaryMeasures.pdf. But see U.S. Department of State, Response of the U.S. Government of 15 April 2002 to the IACHR with regard to the Commission's Decision to Order Precautionary Measures in the Guantanamo Detainees Case, April 15, 2002.

${ }^{55}$ See Senate Committee on the Judiciary, Subcommittee on the Constitution, Restoring the Rule of Law, prepared testimony, Diane Marie Amann et al., 110th Cong., 2nd sess., September 16, 2008, n. 29. The letter directly states that international human rights law "applies in time of war." It refrains from directly stating that the ICCPR applies extraterritorially. Instead, it states that "U.S. treaty obligations regulate U.S. operations even when conducted outside the United States, and then follows up with a series of provisions from the ICCPR, in the context of detention, but equally applicable to targeted killing; it seems evident that this is intended to be a statement about the extraterritorial application of the ICCPR as well as other treaties.

${ }^{56}$ See Harold Hongju Koh, "Written Responses to Pre-Hearing Questions Submitted to Legal AdvisorDesignate Harold Hongju Koh by Senator Richard Lugar, Senate Foreign Relations Committee” (2009), available at http://lugar.senate.gov/sfrc/pdf/KohQFR.pdf, 1.

${ }^{57}$ Amnesty International USA, “An Extrajudicial Execution by the CIA?" Amnesty International, http://www.amnesty.org/en/library/asset/AMR51/079/2005/en/bcffa8d8-d4ea-11dd-8a23d58a49c0d652/amr510792005en.html.

${ }^{58}$ UN Economic and Social Council, Commission on Human Rights, Report of the Special Rapporteur on Extrajudicial, Summary, or Arbitrary Executions, Asma Jahangi, Addendum: Summary of Cases Transmitted to Governments and Replies Received, March 24, 2004, UN Doc. 2004/7/Add.1, pars. 611-12; UN Economic and Social Council, Commission on Human Rights, Extrajudicial, Summary or Arbitrary Executions, Report of the Special Rapporteur, Asma Jahangi, Submitted Pursuant to Commission on Human Rights Resolution 2002/36, January 13, 2003, UN Doc. E/CN.4/2003/3, par. 37. ${ }^{59}$ Cited in United Nations, Office of High Commissioner for Human Rights, http://www2.ohchr.org/english/bodies/chr/special/counter-terrorism.htm.

60 "Remote-Controlled Spy Planes," CBSNews.com, November 6, 2002, available at http://www.cbsnews.com/stories/2002/11/06/attack/main528396.shtml.

${ }^{61}$ For a tiny sample, see notes to Amos N. Guiora, Targeted Killing as Active Self Defense, 36 CASE W. RES. J. INT'L L. 319 (2004). I have not in this chapter devoted attention to Israel, although it has a far more developed jurisprudence around targeted killing than the United States. The reason is that the nature of the long-term conflict, the fact that the conflict takes place in a confined geographic space, the special role of the Israeli Supreme Court in Israeli society and other factors make me believe that the Israeli experience is actually less instructive for the United States than one might otherwise have thought. It seems to me quite inappropriate in the U.S. context to discuss judicial review of targeting killing, for example.

${ }^{62}$ Abraham D. Sofaer, Sixth Annual Waldemar A. Solf Lecture in International Law: Terrorism, the Law, and the National Defense, 126 MiL. L. R. 89 (Fall 1989), at 117-118.

${ }^{63}$ The National Commission on Terrorist Attacks Upon the United States, The 9/11 Commission Report, July 22, 2004, 132.

${ }^{64}$ E.g., Joel Westra, International Law and the Use of Armed Force (New York: Routledge, 2007); Yoram Dinstein, War, Aggression and Self Defense (New York: Cambridge University Press, 2001); Volker Franke, Terrorism and Peacekeeping: New Security Challenges (Westport, CT: Greenwood Publishing Group, 2005). The literature is voluminous, to say the least.

${ }^{65}$ See, e.g., William Walton Keller and Gordon R. Mitchell, Hitting First: Preventive Force in U.S. Security Strategy (Pittsburgh, PA: University of Pittsburgh Press, 2006); George P. Fletcher and Jens David Ohlin, Defending Humanity: When Force is Justified and Why (New York: Oxford University Press, 2008); Alan M. Dershowitz, Preemption: A Knife That Cuts Both Ways (New York: W.W. Norton and Company, 2007).

${ }^{66}$ For a robust assertion of them as opinio juris of the United States government - and a formulation to which the United States government would do well to return today-see Abraham D. Sofaer, Terrorism, the Law and the National Defense, note 62 above. 
${ }^{67}$ Hays Parks, "Memorandum of Law: Executive Order 12333 and Assassination," memorandum, December 1989, 4, 7.

${ }^{68}$ See, e.g., Mayur Patel, “Israel's Targeted Killings of Hamas Leaders,” ASIL Insights, May 2004. It should be noted that the U.S. interpretation of the Caroline Doctrine does not read Webster's apparently confining words as much of a restriction - it would be more accurate, perhaps, to say that the United States uses the Caroline Doctrine less as a constraint than as a recognition of the customary right of anticipatory self-defense.

${ }^{69}$ Matthew C. Wiebe, Comment, Assassination in Domestic and International Law: The Central Intelligence Agency, State-Sponsored Terrorism, and the Right of Self-Defense, 11 TULSA J. COMP. INT'L L. 363, (2003), citing Nathan Canestaro, American Law and Policy on Assassinations of Foreign Leaders: The Practicality of Maintaining the Status Quo, 26 B.C. INT'L COMP. L. REV. 1, 16-17 (2003).

${ }^{70}$ Hays Parks, "Memorandum of Law," 7.

${ }^{71}$ Howard A. Wachtel, Targeting Osama Bin Laden: Examining the Legality of Assassination as a Tool of U.S. Foreign Policy, 55 DUKE L.J. 677, 692 (2005).

${ }^{72}$ Hays Parks, "Memorandum of Law," 7, n. 8.

${ }^{73}$ Murphy, "Cross-Border Operations," manuscript at 25.

${ }^{74}$ Ibid., manuscript at 18.

${ }^{75}$ Ibid.

${ }^{76}$ Armed Activities on the Territory of the Congo (Dem. Rep. Congo v. Uganda), 2005 I.C.J. 168, 223 (December 19, 2005).

${ }^{77}$ See 50 U.S.C. 403-3(d)(5).

${ }^{78}$ Phillip R. Trimble, International Law: United States Foreign Relations Law (New York: Foundation Press, 2002), 250.

79 Ibid.

${ }^{80}$ Ibid., 321.

${ }^{81}$ Foreign Assistance Act of 1974, Public Law 93-559, 93rd Cong., 2nd sess. (1974).

${ }^{82}$ A good short summary of these requirements is found in Alfred Cumming, "Covert Action: Legislative Background and Possible Policy Questions," Congressional Research Service, February 9, 2009.

${ }^{83}$ W. Michael Reisman and James E. Baker, Regulating Covert Action: Practices, Contexts and Policies of Covert Coercion Abroad in International and American Law (New Haven, CT: Yale University Press, 1992), 118.

${ }^{84} 50$ U.S.C.A. $413 \mathrm{~b}(\mathrm{e})$.

${ }^{85}$ Ibid., 124, citing Intelligence Authorization Act for FY 1991, Public Law 102-88, 102nd Cong., 1 st sess. (1991), 105, stat. 429. See also “1991 Acts Senate Report,” no. 102-85; "House Conference Report," no. 102-66; "1991 U.S. Code, Congressional and Administrative News," 193.

${ }^{86}$ Nathan Canestaro, American Law and Policy on Assassinations of Foreign Leaders: The Practicality of Maintaining the Status Quo, 26 Bost. COLL. InT’L COMP. L. REV. 1, 22 (2003).

${ }^{87}$ Ibid.

${ }^{88}$ Boyd M. Johnson III, Executive Order 12,333: The Permissibility of an American Assassination of a Foreign Leader, 25 CORNELL INT'L L. J. 401, 408-409 (1992).

${ }^{89}$ Abraham D. Sofaer, Terrorism, the Law, and the National Defense, 117-118.

${ }^{90}$ See Seymour M. Hersh, "Target Qaddafi," New York Times, February 22, 1987, available at http://www.nytimes.com/1987/02/22/magazine/target-qaddafi.html?sec=\&spon=\&pagewanted=1, reporting that the bombing raid on Libya was understood by the Reagan Administration to be an attempt to kill Qaddafi. Hersh's account has been sharply disputed by military lawyers and others who were involved with the planning of the mission. See, e.g., W. Hays Parks, "Definition of Assassination," Memorandum of International Law Branch, International Affairs Division, Office of the Judge Advocate General, Department of the Army, November 2, 1989.

${ }^{91}$ See Robert F. Turner, Intentional Targeting of Regime Elites: The Legal and Policy Debate, 36 NEW Eng. L. ReV. 785 (2002); Thomas Wingfield, Taking Aim at Regime Elites: Assassination, Tyrannicide and the Clancy Doctrine, 22 MD. J. INT'L TRADE 287 (1999).

${ }^{92}$ Abraham D. Sofaer, Terrorism, the Law, and the National Defense, 122.

${ }^{93}$ See, e.g., Craig R. Whitney, "War on Terror Alters U.S. Qualms about Assassination," International Herald Tribune, March 29, 2004, 2. 
${ }^{94}$ Abraham D. Sofaer, Terrorism, the Law, and the National Defense, 122.

${ }^{95}$ See, e.g., Curtis Bradley and Jack Goldsmith, Customary International Law as Federal Common Law: A Critique of the Modern Position, 110 HARV. L. R. 4 (1997); Jack Goldsmith and Eric Posner, The New International Law Scholarship, 34 GA. J. INT'L COMP. L. 463 (2006), highlighting the limitations of customary law.

${ }^{96}$ The Israeli targeted killing of Salah Shehadeh in Gaza in 2002 illustrates where things would likely go. Shehadeh was head of the military wing of Hamas, and on the night of July 22, 2002, an Israeli F-16 dropped a bomb on his residential Gaza house, killing him — but also his wife, three of their children and eleven others, mostly children. Legal proceedings were initiated in Britain and Spain against the Israeli commanders, as well as an Alien Tort Statute suit in the United States. It would be a mistake to have any illusion that this is not the trajectory of legal actions against the United States and its officials down the road.

${ }^{97}$ Kim Sengupta, “Army is Fighting British Jihadists in Afghanistan,” The Independent, February 25, 2009. ${ }^{98}$ See W. Hays Parks, "Memorandum of Law: Executive Order 12333 and Assassination," memorandum, DAJA-1A (27-1a), December 1989.

${ }^{99}$ Guy Faulconbridge, "Russian Laughs Off Threat of Poisoning Extradition," Washington Post, January 26, 2007; Associated Press, "Russia Refuses British Request to Extradite Suspect in Poisoned Spy Case," International Herald Tribune, July 5, 2007; Associated Press, "Putin Says British Calls for Lugovoi Extradition 'Stupidity,", International Herald Tribune, June 4, 2007.

${ }^{100}$ See Eric A. Posner and Adrian Vermuele, Terror in the Balance: Security, Liberty, and the Courts (New York: Oxford University Press, 2007) for a discussion of cost-benefit analysis in the counterterrorism context.

${ }^{101}$ This strategic political question is discussed at Kenneth Anderson, "Gaming Spain and Universal Jurisdiction,” Opinio Juris Blog, May 15, 2009, http://opiniojuris.org/2009/05/15/gaming-spain-anduniversal-jurisdiction/.

${ }^{102}$ For example, as an amendment to the National Security Act of 1947, 50 U.S.C. 401 (2005).

103 Trimble, International Law, 252. The proposal for a charter dating to the 1970's "would have established extensive substantive standards for covert operations, prohibited a number of acts like assassinations of foreign leaders, and created elaborate procedures for decision-making. At one point the proposed legislation was 263 pages long. It fell of its own weight." Ibid., 252. Unfettered discretion is not the right approach - but neither is the attempt at comprehensive managerial legislation.

${ }^{104}$ Marc Sageman, Leaderless Jihad: Terror Networks in the Twenty-First Century (Philadelphia: University of Pennsylvania Press, 2008); Marc Sageman, Understanding Terror Networks (Philadelphia: University of Pennsylvania Press, 2004). 